\title{
Hospital based cancer registry in Cipto Mangunkusumo hospital Jakarta
}

Wilfried Berdin Sibuea·, R Rukmini Mangunkusumo\#, Nurul Akbar•, Abidin Widjanarko•, Djajadiman Gatot1, Endang Windiastut/, Mochtar Hamzah ${ }^{00}$ Sonar Soni Panigoro', Joedo Prihartono\Ening Krisnuhono\#, Lisnawati\#, Sri Mulya Sekar Utami"', Irwan Ramli"', Averdi Roezin+, Sigit Pribadi’ Iik Wilarso ${ }^{0}$, I Made Nasal, Santoso Cornain\#

\begin{abstract}
Abstrak
Registrasi kanker berbasis rumah sakit di RSUPN Cipto Mangunkusumo, Fakultas Kedokteran Universitas Indonesia, telah dimu/ai tahun 1997, bertujuan untuk memberi data bagi program pengendalian kanker dan membanlu perencanaan rumah sakit. Maka/ah ini menyajikan registrasi kanker sepanjang tahun 1997-1998. Data dari semua pasien kanker yang baru terdiagnosis dicatat pada Formulir Registrasi Kanker. Yang didata ialah identitas pasien, demografi dan kultur, penilaian tumor dan usia, serta penatalaksanaan. Terdapat 2144 (0.48\%) penderita kanker diantara 444.178 pasien baru yang berobat ke RSCM. Perbandingan perempuan dan laki-laki ada/ah 1.7: 1. Usia terbanyak pada perempuan ada/ah 35-44 tahun, pada /aki-laki 45-54 tahun. Usia ratarata saat terdiagnosis umumnya lebih muda dibanding senter lainnya. Pada perempuan, kanker terbanyak ada/ah lamker serviks, disusul o/eh payudara dan nasofaring sedang pada laki-/aki terbanyak nasofaring, sumsum tu/ang dan hati. Pada anak, terbanyak ada/ah leukemia limfositik akut, leukemia non limfositik akut, retinob/astoma dan nefroblastoma. Pendidikan penderita perempuan lebih rendah dibanding laki-laki. Perempuan penderita kanker serviks. kulit, sumsum tu/ang, kelenjar getah bening dan /aki-/aki penderita kanker sumsum tulang, kelenjar getah bening dan mata mempunyai pendidikan yang lebih rendah. Sebanyak 85\% diagnosis ditegakkan secara mikroskopik. Jum/ah kanker stadium awa/ lebih rendah dibanding stadium /anjut (47\% vs 53\%). Pada tahun 1998 terapi awal yang paling banyak diberikan ada/ah berturut-turut radioterapi, bedah dan kemoterapi. Hanya 45\% pasien yang mempero/eh terapi da/am 3 bu/anpertama sete/ah diagnosis.
\end{abstract}

\begin{abstract}
+ Department of Surgery, Faculty of Medicine University of Indonesia, Jakarta, Indonesia

- Department of Community Medicine, Faculty of Medicine

University of Indonesia, Jakarta , Indonesia

Depanment of Radiology, Faculty of Medicine University of Indonesia, Jakarta, Indonesia

+ Department of ENT, Faculty of Medicine University of Indonesia, Jakarta, Indonesia

"Department of Obstetrics and Gynecology, Faculty of Medicine

University of Indonesia, Jakarta, Indonesia

${ }^{\circ}$ Computer Science Center, University of Indonesia, Jakarta

- Department of Internal Medicine, Faculty of Medicine University of

Department of Anat omic Pathology, Faculty of Medicine University of

Unedicine Unity of Indonesia Indonesia
\end{abstract}

The Hospital Based Cancer Registry in Registry in Cipto Mangunkusumo National Center General Hospital (RSCM), the teaching hospital of the Faculty of Medicine University of Indonesia, was set up in 1997. Its aims were toprovide information on the magnitude of cartcer problems, and data for focussing cancer control programs, to facilitate thefollow up and to help plan hospital facilities . This paper presents a summary of the cancer registry data collected during the period of 1997-1998. Data from al newly diagnosed cancer patients was recorded in Cancer Registration Forms by the oncology doctors. The collected items of information were patient 's identification, demographic and cultural items, the tumor and its investigations, and the treatment. There were 2144 (0.48\%) cancer patients among 444,178 new patients treated in RSCM hospital. The female to male patients ratio was $1.7: 1$. The age peaked in females within 35-44 years, and in males within 45-54 years. In general. the mean age at diagnosis of various cancer was younger compared to other centers. In females, the most common cancers were cervical, breast, and nasophayngeal, and in males, they were nasopharyngeal, bone marrow, and liver cancers. In children, the most common cancers were acute lymphocytic leukemia, acute nonlymphocytic leukemia, acute non-/ymphocytic leukemia, retinoblastoma, and nephrob/astoma. Female patients had lower educational level than males. Females with cervical, skin, bone marrow, lymph nodes cancer and males with bone marrow, lymph nodes and eye malignancy had lower educational level. There were 85\% patients diagnosed by microscopic examination. The number of early stage cancer was lower corned to late stage cases (47\% vs 53\%). In 1998, the most frequent initial treatment was radiotherapy, followed by surgery and chemotherapy, and only $45 \%$ patients received treatments within 3 months after diagnosis.
Keywords: Cancer registry, site, age, education, staging,
diagnosis, treatment

Keywords: Cancer registry, site, age, education, staging,
diagnosis, treatment

The incidence of cancer in Indonesia has been observed to increase every year. According to the estimation of the Ministry of Health the incidence rate of cancer was about 100 per 100.000 people. As the people's awareness about this dreaded disease is 
growing, it is of interest to see that several social organization for cancer control have been established such as Nederlands Indische Kanker Instituut in 1933 in Bandung, Cancer foundations in several cities in Indonesia, Wisnuwardhana Cancer Foundation in Surabaya, and Indonesian Cancer Foundation (Yayasan Kanker Indonesia) in 1977 in Jakarta, followed by establishment of its branches in 27 provinces in Indonesia. 2

Since 1989 the Ministry of Health has actively participated in Cancer Control and instructed to establish a hospital-based Integrated Cancer Control Team (ICCT) in every big hospital. In 1996, such a team has been established in Cipto Mangunkusumo National Center General Hospital (RSCM) which functions as the teaching hospital of Medical Faculty of University of Indonesia and the top referral hospital in the Western part of Indonesia by the director of the hospital and with the approval of the Dean of Medical Faculty, University of Indonesia. One of the tasks of this team is to perform hospital based cancer registry, which will provide information on the magnitude of cancer problems and data for focussing cancer control, i.e. the total number of patients annually, site of cancers, data on survival of patients, the ratio between localized and advanced cases at the time of diagnosis. $^{3}$ In addition, to facilitate the follow up of all patients and to furnish information about the demands made-by cancer patients on the facilities, equipment and human resources of the hospital.

This paper presents a summary of the cancer registry data collected during the period of 1997-1998. Ten most frequent tumors were given according to gender. The data was analyzed against age, clinical and histopathological diagnosis, extent of diseases and the nature of initial treatment given to cancer patients in 1998. They were also evaluated against demographical data in particular educational background and age.

\section{MATERIALS AND METHODS}

The Hospital Based Cancer Registry in Cipto Mangunkusumo Hospital was officially established in 1997. To enasure an easy collection of data from different department which were treating cancer, a Cancer Registration Form (CRF) was developed based on the form issued by the Ministry of Health in 1995.

Data from all newly diagnosed cancer patients who visited Cipto Mangunkusumo Hospital from January 1, 1997 until December 31, 1998 was recorded in
CRF. Table 1 shows the items of information which should be collected. ${ }^{4}$

Table 1. Items of Patients Information which should be collected in the Registration Form

\begin{tabular}{ll}
\hline No. Items of Information & No. Items of Information \\
\hline I. Name of Hospital & 15. Type of Patient \\
2. Code of Hospital & 16. Incidence Date \\
3. Medical Record Number & 17. Most Valid Diagnosis \\
4. Cancer Registry Number & 18. Cli nical Diagnosis \\
5. Name of Patient & 19. Primary Site: Topography (ICD-0) \\
6. Number of Identity Card & 20. Histological Diagnosis \\
7. Gender & 21. Morphology (ICD-0) \\
8. Date of Birth & 22. Clinical Extent of Disease \\
9. Address & \multicolumn{1}{c}{ before Treatment } \\
10. Racial Group & 23. Multiple Primary Neoplasm \\
11. Religion & 24. Date of Death \\
12. Marital Status & 25. Cause of Death (!CD) \\
13. Education & 26. Name of Oncologist \\
14. Occupation & 27. Name of Supervisor \\
\hline
\end{tabular}

The form were sent to cancer treating departments and were filled and completed by the treating medical, surgical or radiation oncology doctors and approved by their supervisors. Then these forms were forwarded to the Hospital Cancer Registry for further processing: coding, verification, analysis and reporting. ${ }^{5}{ }^{6}$ For the coding of all registered tumors, the second edition of the International Classification of the Diseases for Oncology (ICD-0) was used. ${ }^{7}$

In this study the level of education from all patients was recorded and was used to examine whether there was a differential change in cancer prevalence across educational categories. It was categorized into illiterate (unable to read and write), able to read and write, elementary school graduate (six years of schooling completed), junior high school (9 years of schooling completed), senior high school graduate (twelve years of schooling completed), academy or university graduate (more than 15 years of schooling completed). Beginning from 1998 on, the information about the nature of initial therapy and the data on which therapy commenced were also collected.

\section{RESULTS AND DISCUSSION}

.A descriptive study was completed from January 1, 1997 until December 31, 1998. There were 444.178 new patients suffered from various diseases who visited Cipto Mangunkusumo Hospital, among them $2144(0.48 \%)$ were cancer patients, consisting of 798 (0.18\%) males and 1346 (0.30\%) females. Sukardja reported $2.95 \%$ cases of the total admitted patients ${ }^{9}$ and according to the study of Partoatmodjo et al, ${ }^{10}$ it 
was $1.2 \%$. The female to male ratio was $3.4: 2$ (1346:798), the similar ratio was reported by Sukardja but it was 2:3 in Singapore. ${ }^{11}$

Age and Site of Malignant Neoplasm

The number of cases by primary site and age in females and males are shown in table $i$ and $i$ (appendix), respectively. Cancer could be found at any age. The age ranged from several months to over 65 years, with a preponderance of cases between 35 64 years and a peak within 35 - 44 years in females, while in males the preponderance of cases was more than 45 years of age and a peak within 55 - 64 years (figure 1). The study of Sukardja ${ }^{9}$ showed preponderance of cases between 35 - 64 years and a peak within 45 54 years in males as well as in females. These ages were younger than in the developed countries, over 75 years in the Philippine ${ }^{12}$ and in Singapore. ${ }^{11}$ The nu mber of cases occurred in children before 5 years of age were $95(4.4 \%)$ and in the age group of $5-14$ years were 128 (6\%). The number of males was higher than females. These figures were similar to that m S $_{\text {mgapore. " }}$

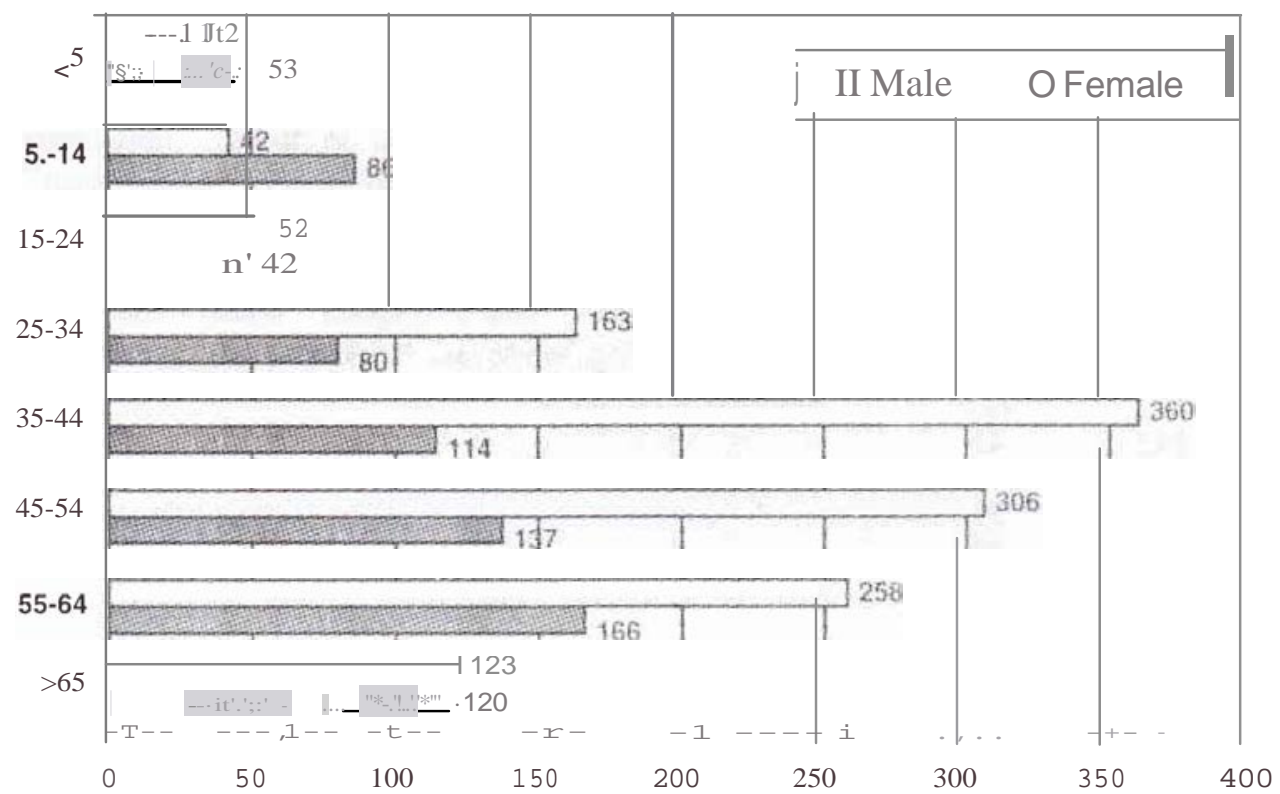

Figure 1. Age distribution of malignant neoplasm in 2144 patients : 798 males and 1346/emales

Table 2. Number of New Cases in Ten Most Frequent Cancers by Age and Site

\begin{tabular}{|c|c|c|c|c|c|c|c|c|c|c|}
\hline \multirow{2}{*}{ Topography } & \multicolumn{8}{|c|}{ Age } & \multirow{2}{*}{ Total } & \multirow{2}{*}{$\left.\mathrm{Rf}^{*}\right)$} \\
\hline & $<5$ & $5-14$ & $15-24$ & $25-34$ & $35-44$ & $45-54$ & $55-64$ & $>65$ & & \\
\hline Cervix uteri & 0 & $\mathbf{I}$ & $\mathbf{I}$ & 33 & 164 & 150 & 94 & 39 & 482 & 22.48 \\
\hline Nasopharynx & 0 & 6 & 16 & 23 & 55 & 57 & 27 & 11 & 195 & 9.09 \\
\hline Breast & 0 & 0 & 2 & 23 & 61 & 41 & 37 & 8 & 172 & 8.02 \\
\hline Bone marrow & 45 & 64 & 12 & 12 & 13 & 10 & 13 & 2 & 171 & 7.98 \\
\hline Colorectal & 0 & 0 & 5 & 19 & 21 & 21 & 31 & 17 & 114 & 5.32 \\
\hline Lymph nodes & $\cdot 6$ & J0 & 7 & 14 & 28 & 16 & 18 & 9 & 108 & 5.04 \\
\hline Skin & 3 & 1 & & 3 & 9 & 12 & 35 & 38 & 102 & 4.76 \\
\hline Liver & 0 & & 0 & 5 & 14 & 20 & 29 & 21 & 90 & 4.2 \\
\hline Thyroid & 0 & 0 & 6 & 22 & 18 & 13 & 13 & 5 & 77 & 3.59 \\
\hline Eye & 12 & 9 & 1 & 6 & 5 & 13 & 9 & 7 & 62 & 2.89 \\
\hline Total & 66 & 92 & 51 & 160 & 388 & 353 & 306 & 157 & 1573 & \\
\hline Percentage & 4.2 & 5.8 & 3.2 & 10.2 & 24.7 & 22.4 & 19.5 & 10 & 100 & \\
\hline
\end{tabular}

*) Rf = Relative frequency 
The number of ten most frequent cancers was 1573 cases, representing $73 \%$ (1573:2144) of all cancers (table 2). The most frequent cancer encountered was cervical (22.5\%), followed by naso-pharyngeal (9\%), breast (8\%), bone marrow (8\%), colorectal (5.3\%), lymph nodes (5\%), skin (4.8\%), liver (4.2\%), thyroid (3.6\%) and eye (2.9\%). Cervical carcinoma and breast cancers were more frequent in the age group of 35-44 years, nasopharyngeal cancer in 45-54 years, bone marrow in 0-15 years and colorectal in 55-64 years. The data collected by Sukardja in East Java shpwed that the most frequent cancer was cervical cancer, followed by liver and breast cancer. ${ }^{9}$

Table 3. Mean and Median Age at Diagnosis in Ten Most Frequent Cancers

\begin{tabular}{lccc}
\hline Cancer & Total Cases & Mean & Median \\
Cervix uteri & 482 & 47.8 & 47 \\
Nasopharynx & 195 & 42.9 & 43 \\
Breast & 172 & 45.5 & 44 \\
Bone marrow & 171 & 18.5 & 10 \\
Colorectal & 114 & 48.5 & 49.5 \\
Lymph nodes & 110 & 39.3 & 42 \\
Skin & 102 & 58.2 & 60 \\
Liver & 90 & 54.2 & 57 \\
Thyroid & 77 & 41.6 & 39 \\
Eye & 62 & 34.9 & 36.5 \\
\hline
\end{tabular}

'in years
The mean age at diagnosis of cervical caRcer was 47.8 years and breast cancer was 45.5 years (table 3 ). In USA these cancers were diagnosed at older age, ${ }^{14.15}$ while the mean age of cervical cancer and breast cancer was 54 years and 57 years respectively. According to Ramli, ${ }^{19}$ the mean age of breast cancer was 46.9 years. The median age of nasopharyngeal carcinoma was 43 years, younger than the study of Sutjipto et al who found 50 years as the median age. ${ }^{16}$

In females the total number of ten most frequent cancers was 1102 (82\%), and the most frequent cancer encountered was cervical cancer and the second was breast cancer (table 4). In other countries of Asia like the Philippines breast, cervical and lung cancers were the most common ones, and in India, ${ }^{17}$ they were cervical, breast and esophageal cancers. But in Japan ${ }^{13}$ and USA, cancer of the cervix has been steadily decreased. In USA, it only ranked as cancer number eight. ${ }^{14}$ In Japan ${ }^{13}$ and Singapore ${ }^{11}$ breast cancer was also increasing while in USA it was $32 \%$ of all cancers in females. ${ }^{15}$

Table 4. Number of New Cases in Ten Most Frequent Cancers in Females by Age and Site

\begin{tabular}{|c|c|c|c|c|c|c|c|c|c|c|}
\hline \multirow{2}{*}{ Topography } & \multicolumn{8}{|c|}{ Age } & \multirow{2}{*}{ Total } & \multirow{2}{*}{$\mathrm{Rf}$} \\
\hline & $<5$ & $5-14$ & $15-24$ & $25-34$ & $35-44$ & $45-54$ & $55-64$ & $>65$ & & \\
\hline Cervix uteri & 0 & & & 33 & 164 & 150 & 94 & 39 & 482 & 35.8 \\
\hline Breast & 0 & 0 & 2 & 23 & 61 & 41 & 36 & 8 & 171 & 12.7 \\
\hline Nasopharynx & 0 & & 5 & 7 & 20 & 21 & 7 & 2 & 63 & 4.68 \\
\hline Throid & 0 & 0 & 4 & 19 & 16 & 11 & 9 & 4 & 63 & 4.68 \\
\hline Colorectal & 0 & 0 & 5 & 7 & I I & I I & 17 & I I & 62 & 4.61 \\
\hline Skin & & & & 2 & 4 & 5 & 21 & 27 & 62 & 4.61 \\
\hline Bone marrow & 20 & 13 & 3 & 6 & 6 & 4 & 7 & 0 & 59 & 4.38 \\
\hline Ovary & 0 & 2 & 8 & 10 & 18 & 8 & 10 & 3 & 59 & 4.38 \\
\hline Lymph nodes & 2 & 2 & 3 & 6 & 16 & 8 & 7 & & 45 & 3.34 \\
\hline Placenta & 0 & 0 & 7 & 21 & 8 & 0 & 0 & 0 & 36 & 2.67 \\
\hline Total & 23 & 20 & 39 & 134 & 324 & 259 & 208 & 95 & 1102 & \\
\hline
\end{tabular}


Table 5. Number of New Cases in Ten Most Frequent Cancers in Males by Age and Site

\begin{tabular}{|c|c|c|c|c|c|c|c|c|c|c|}
\hline \multirow{2}{*}{ Topography } & \multicolumn{8}{|c|}{ Age } & \multirow{2}{*}{ Total } & \multirow{2}{*}{$\mathrm{Rf}$} \\
\hline & $<5$ & $5-14$ & $15-24$ & $25-34$ & $35-44$ & $45-54$ & 55-64 & $>65$ & & \\
\hline Nasopharynx & 0 & 5 & LL & 16 & 35 & 36 & 20 & 9 & 132 & 16.5 \\
\hline Bone marrow & 25 & 51 & 9 & 6 & 7 & 6 & 6 & 2 & 112 & 14 \\
\hline Liver & 0 & $\mathbf{I}$ & 0 & 4 & 10 & 18 & 18 & 19 & 70 & 8.77 \\
\hline Lymph nodes & 4 & 8 & 4 & 8 & 12 & 8 & 11 & 8 & 63 & 7.89 \\
\hline Colorectal & 0 & 0 & 0 & 12 & 10 & 10 & 14 & 6 & 52 & 6.52 \\
\hline Skin & 2 & 0 & 0 & I & 5 & 7 & 14 & 11 & 40 & 5.01 \\
\hline Eye & 9 & 7 & & 0 & 3 & 6 & 7 & 4 & 37 & 4.64 \\
\hline Bladder & 0 & 0 & $\mathbf{I}$ & 3 & 3 & 8 & 14 & 7 & 36 & 4.51 \\
\hline Prostate gland & 0 & 0 & 0 & 0 & 0 & 2 & 7 & 20 & 29 & 3.63 \\
\hline Kidney & 5 & & 0 & 3 & 2 & 2 & 3 & 2 & 18 & 2.26 \\
\hline Total & 45 & 73 & 26 & 53 & 87 & 114 & 88 & 88 & 589 & \\
\hline
\end{tabular}

The number of ten most frequent cancers in males was 589 represented $74 \%$ of all cancers in males (table 5). Nasopharyngeal carcinoma (NPC) was the most frequent cancer encountered, followed by bone marrow and liver malignancy. Nasopharyngeal malignancy was more frequent in the age group of 4554 years, bone marrow in $0-14$ years and liver in the age group of $>65$ years. The number of NPC's cases in males were 132 and in females were 63 cases. Male to female ratio was 2.1: 1 . According to the study of Sutjipto et al, the number of NPC in the year of 1980 1981 in our hospital was 219 cases, 154 males and 65 females, ${ }^{16}$ bu t the male to female ratio was similar. This cancer ranks number five in Singapore and number seven in tile Philippines but in Indonesia it remains the most frequent cancer in males.

Tabel 6. Number of New Cases in Four Most Frequent Cancers in Child ren by Age and Site

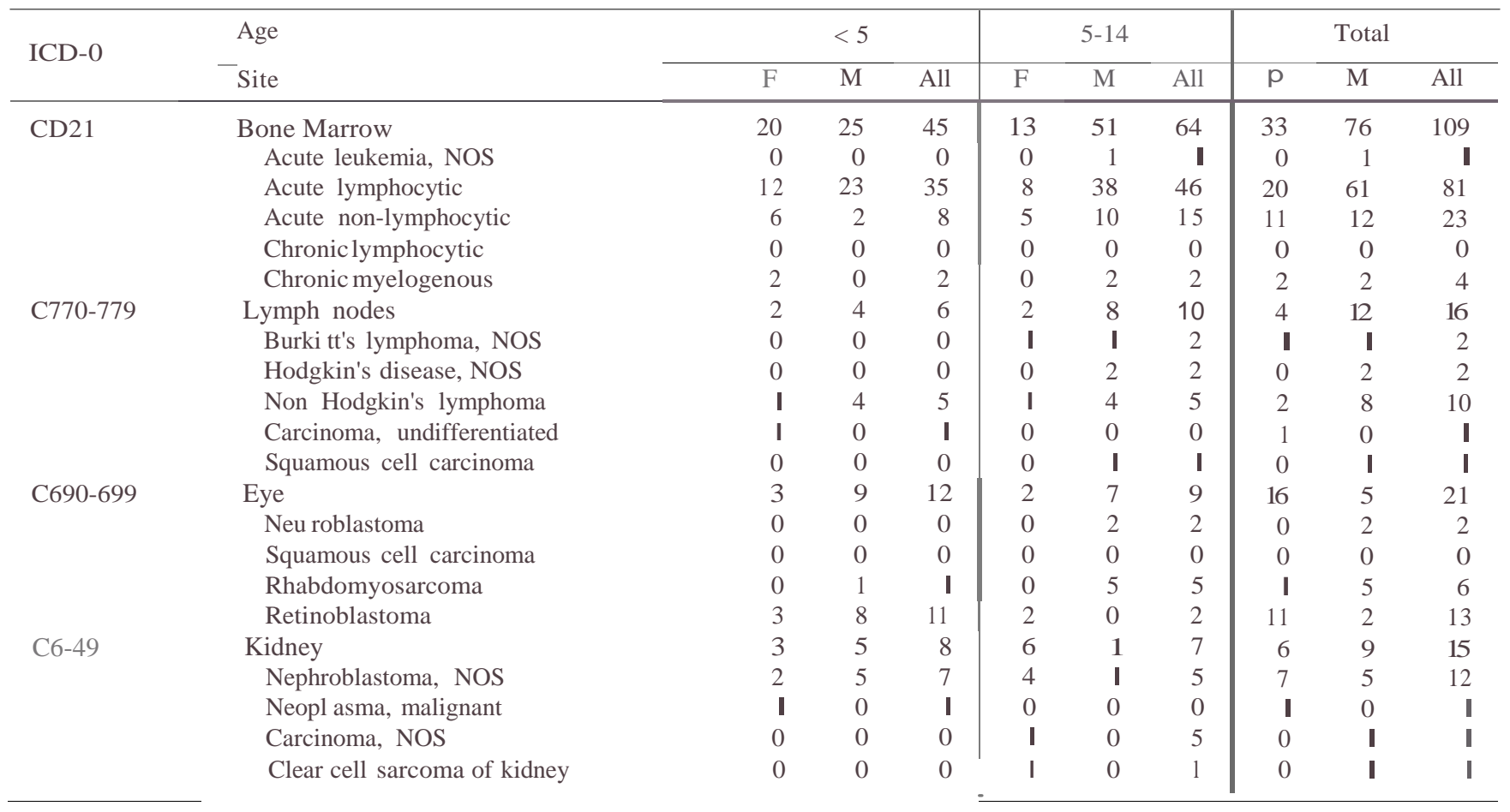

\footnotetext{
$\mathrm{F}=$ Female $\quad \mathrm{M}=$ Male $\quad$ NOS $=$ Not Otherwise Specified
} 
In children, malignancy of the bone marrow, eye, lymph nodes and kidney were the most common cancers [table 6 and table iii (appendix)]. The male of female ratio was 1.6 : 1 . Among 109 cases of bone marrow malignancy, there were 105 (96.3\%) cases of acute leukemia consisting of $81(74.3 \%)$ cases of acute lymphocytic leukemia, and 23 (21.1\%) cases of acute non-lymphocytic leukemia. There were 4 cases of chronic myelocytic leukemia. Thirty five (35) patients of acute lymphocytic leukemia aged less than 5 years and 48 cases were in the age group of 5- 14 years (table 6). Male to female ratio was 3: 1 ; the mean age at the time of diagnosis was 6 years (table 7). These figures were similar to data in the Philippines ${ }^{12}$ and USA. ${ }^{20}$ The most common tumor of the eye was retinoblastoma (62\%) in which female to male ratio was $5.5: \mathrm{I}$, and the mean age at the time of diagnosis was 4 years. There were I 1 (84.6\%) patients aged below 5 years. In Surabaya, the number of retinobla toma patients were $29.5 \%$ of all eye cancers and female to male ratio was $1.5: 1 .^{21}$ In USA, the number of females was higher than males, the age peaked at 17 months, and $90 \%$ of the cases occurred below 5 years of age. ${ }^{22}$ The most frequent cancer of the kidney was nephroblastoma (80\%), female to male ratio was $1.4: 1$, the mean age at the time of diagnosis was 3 years, and the age peaked Jess than 5 years. In USA, the mean age at diagnosis was 2.5 years. $^{23}$ Among the malignancy of lymph nodes, nonHodgkin' s lymphoma was the most frequent one (22.2\%). The mean ag_e at the time of diagnosis was 5 years and male to female ratio was $4: 1$. In USA, the age peaked at 9-10 years, and it was 2.5 times greater: in male than infemales. ${ }^{14}$

Table 7. Mean and Median Age at Diagnosis in Four Most Frequent Cancers

\begin{tabular}{lccc}
\hline Cancer & Total cases & Mean & Median \\
\hline Acute lymphocytic & 81 & 6 & $S$ \\
Acute non-lymphocytic & 23 & 6 & 6 \\
Retinoblastoma & 13 & 4 & 3 \\
Nephroblastoma, NOS & 12 & 3 & 3 \\
Non-Hodgki n's lymphoma & 10 & 5 & 4
\end{tabular}

* in years

\section{Education}

Figure 2 presents the number of new cases according to educational level and gender in 2144 patients, 798 males and 1346 females. There were 280 (35\%) male patients who belonged to lower educated group (illiterate-elementary) and 375 (47\%) to higher educated group (high school-university), but in females, thera were $643(48 \%)$ patients with low level of education and 509 (38\%) patients with high level of education. It is clear that the number of male patients in the higher educated group was greater than in the lower, while among female patients the number of lower educated group was greater than the higher one.

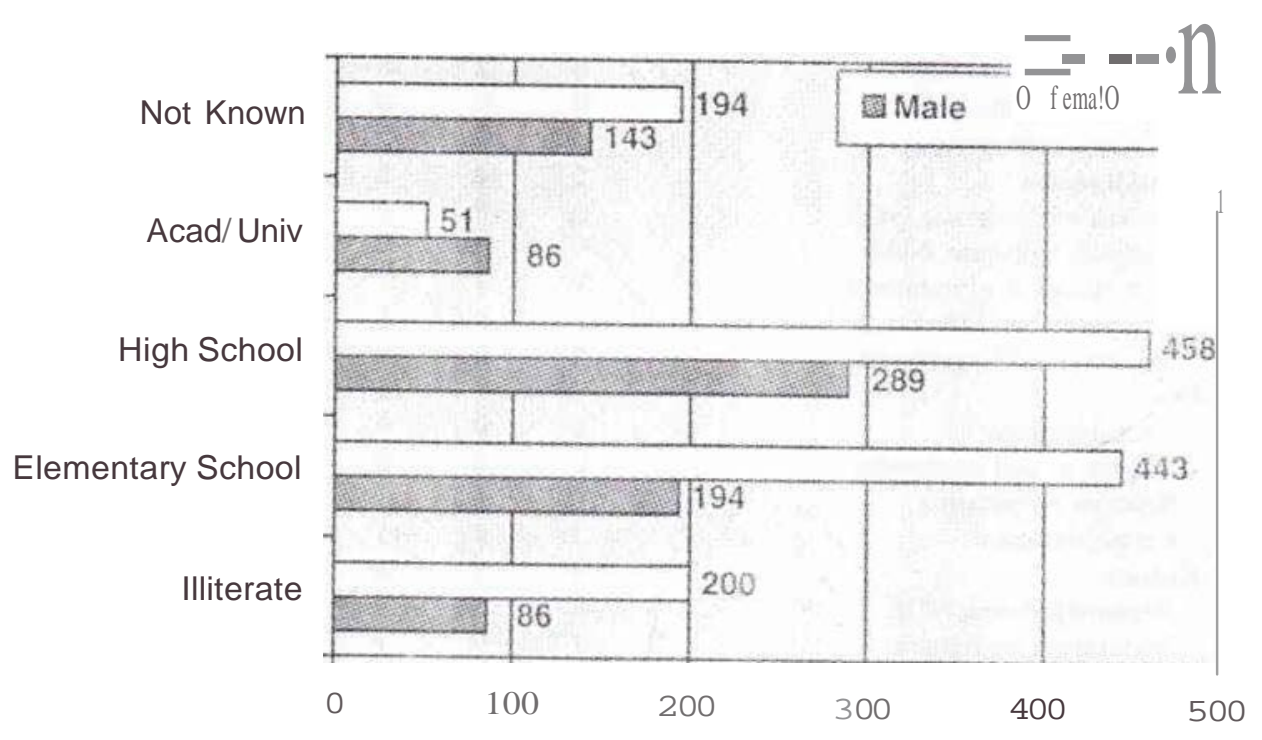

Figure 2. Distribution of New Cancer Cases according to education and greater 
Table 8. Education Level in Ten Most Frequent Cancers in Females

\begin{tabular}{|c|c|c|c|c|c|c|}
\hline Topography & Illiterate & $\begin{array}{c}\text { Elementary } \\
\text { School }\end{array}$ & $\begin{array}{c}\text { High } \\
\text { School }\end{array}$ & $\begin{array}{l}\text { Academy/ } \\
\text { University }\end{array}$ & $\begin{array}{c}\text { Not } \\
\text { Known }\end{array}$ & Total \\
\hline Cervix uteti & 73 & 218 & 154 & 10 & 27 & 482 \\
\hline Breast & 5 & 30 & 82 & 11 & 43 & 171 \\
\hline Nasopharynx & 4 & 21 & 25 & 2 & 11 & 63 \\
\hline Thyroid & 4 & 17 & 21 & 4 & 17 & 63 \\
\hline Colorectal & 8 & 14 & 31 & 5 & 4 & 62 \\
\hline Skin & 17 & 23 & 15 & 0 & 7 & 62 \\
\hline Bone marrow & 20 & 10 & 6 & 0 & 23 & 59 \\
\hline Ovary & 9 & 22 & 22 & 4 & 2 & 59 \\
\hline Lymph nodes & 1 & 12 & 6 & I & 25 & 45 \\
\hline Placenta & 2 & 8 & 23 & 3 & 0 & 36 \\
\hline Total & 143 & 375 & 385 & 40 & 159 & 1102 \\
\hline Percentage & 13 & 34.0 & 34.9 & 3.6 & 14.4 & 100 \\
\hline
\end{tabular}

In females, the number of patients with cervical $(60 \%)$, skin (64\%), ovary (52\%) and bone marrow (50\%) cancer was higher in lower educated group, but more patients with breast, thyroid, nasopharyngeal and colorectal cancers were found in higher educated group (table iv and 8). Figure 3 shows the most frequent cancers in females with low level of education. Low educational level of cancer patients was a significant risk factor for cervical ${ }^{18}$ and breast cancers. ${ }^{19}$

Table $\mathrm{v}$ and table 9 show the number of new cases by primary sites and education in all and ten most frequent cancers in males respectively. The number of patients with bone marrow, lymph nodes and eye malignancies was higher in lower educated group, while the other numbers were in higher educated group. Most of patients with bone marrow malignancy were acute leukemia $(104 / 112$ - 93\%) with the mean age at diagnosis was in the preschool period (6 years of age), so they could not be included in lower educated group. The similar fact also occurred in eye malignancy.

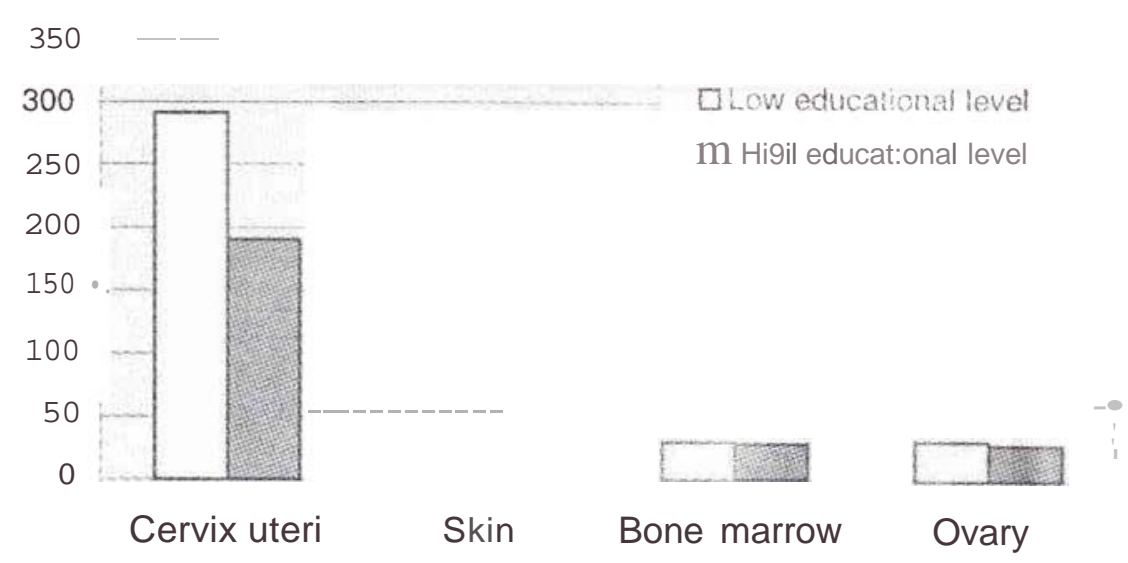

Figure 3. Four mostfrequent cancers infemales with low educational level 
Table 9. Education Level in Ten Most Frequent Cancers in Males

\begin{tabular}{lcccccc}
\hline Topography & Illiterate & $\begin{array}{c}\text { Elementary } \\
\text { School }\end{array}$ & $\begin{array}{c}\text { High } \\
\text { School }\end{array}$ & $\begin{array}{c}\text { Academy/ } \\
\text { University }\end{array}$ & $\begin{array}{c}\text { Not } \\
\text { Known }\end{array}$ & Total \\
\hline Nasopharynx & 5 & 31 & 60 & 14 & 22 & 132 \\
Bone marrow & 30 & 36 & 14 & & 31 & 112 \\
Liver & 4 & 9 & 23 & 10 & 24 & 70 \\
Lymph nodes & 6 & 13 & 14 & 28 & 63 \\
Colorectal & 0 & 14 & 30 & 4 & 5 & 52 \\
Skin & 4 & 12 & 17 & 5 & 2 & 40 \\
Eye & 24 & 11 & 17 & 6 & 1 & 37 \\
Bladder & & 10 & 8 & 10 & 4 & 36 \\
Prostate & 4 & & 8 & 4 & & 29 \\
Kidney & 79 & 139 & 199 & 57 & 115 & 18 \\
Total & 13.4 & 23.6 & 33.8 & 9.7 & 19.5 & 589 \\
Percentage & & & & & 100 \\
\hline
\end{tabular}

\section{Clinical Extent of the Disease}

Table vi presents the number of 1617 new cases by primary sites and staging. The number of cancer patients with stage 0 (in itu) was $3.46 \%$, stage I (localized) 43.85\%, stage II (direct extension) $22.02 \%$, stage III (regional lymph nodes involvement) $21.83 \%$ and stage IV (distant metastases) $8.84 \%$. There were 171 cases of bone marrow malignancy consisting of 131(76.6\%) cases of acute leukemia, 24
(14\%) cases of chronic leukemia, $1(0.6 \%)$ leukemia NOS, 6 (3.5\%) multiple myeloma, 6 (3.5\%)

polycythemia vera and $3(1.8 \%)$ others. The data of ten most frequent cancers as presented in table 10 showed two different patterns, namely tumors mostly found in the early stage (stage 0-I) and tumors mostly found in the late stage (stage II-IV). The former one consisted of cervical, skin, thyroid, ovary and eye (figure 4), while the latter were nasopharynx, breast, colorectal, lymph nodes and liver cancers (figure 5).

Table I0. Primary site and staging in ten most frequent cancers

\begin{tabular}{|c|c|c|c|c|c|c|}
\hline Extension & St. 0 & St. 1 & St. 2 & St. 3 & St. 4 & Total \\
\hline Cervix Uteri & 14 & 234 & 162 & 17 & 8 & 435 \\
\hline Nasopharynx & 0 & 8 & 19 & 141 & 4 & 172 \\
\hline Breast & 5 & 73 & 6 & 53 & 24 & 161 \\
\hline Colorectal & 4 & 42 & 20 & 14 & 17 & 97 \\
\hline Lymph nodes & 0 & 5 & 8 & 93 & 4 & 110 \\
\hline Slcin & 6 & 60 & 15 & 8 & & 90 \\
\hline Liver & 0 & 6 & 2 & 81 & & 90 \\
\hline Thyroid gland & 0 & 45 & 6 & 18 & 4 & 73 \\
\hline Eye & 5 & 23 & 15 & 4 & 5 & 52 \\
\hline Ovary & 4 & 25 & 18 & 2 & 3 & 52 \\
\hline Total & 38 & 521 & 271 & 71 & 71 & 1332 \\
\hline Pecentage & 2.9 & 39.1 & 20.3 & 5.3 & 5.3 & 100 \\
\hline
\end{tabular}




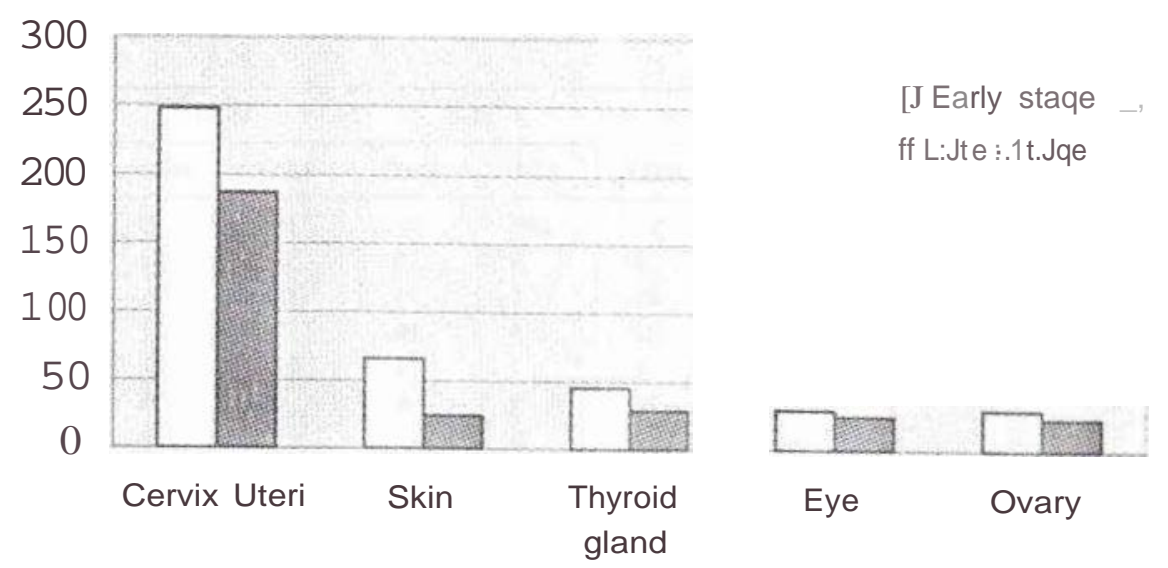

Figure 4. Five most frequent cancers found in the early stage
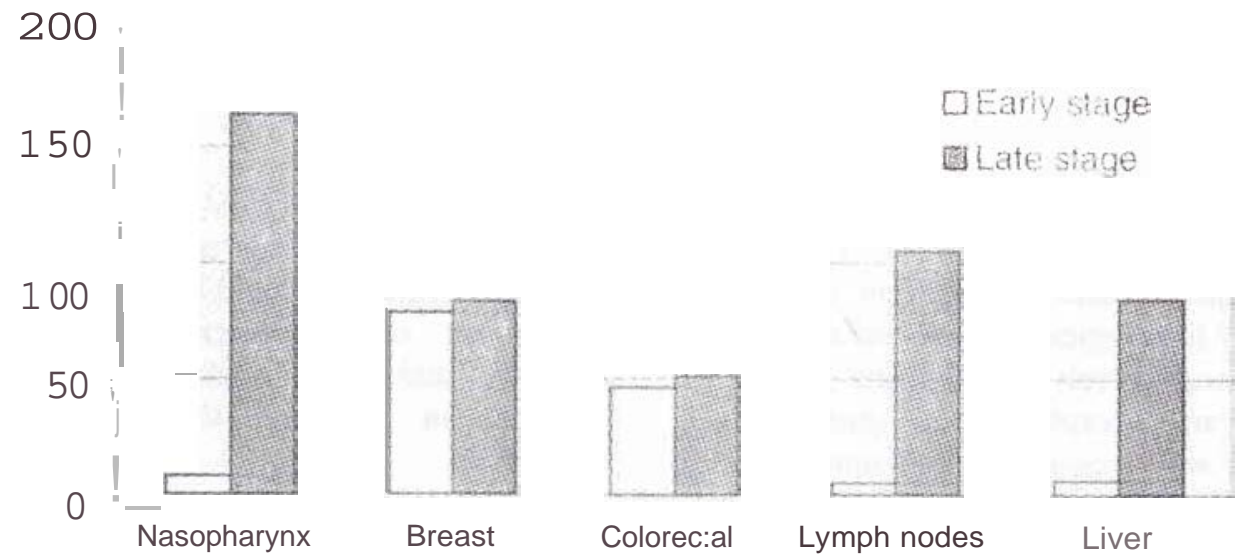

Figure 5. Five mostfrequent cancersfound in the late stage

Table vii shows the number of all cancer patients by sites, education and staging. The number of stage 0 and II cases with low educational level was greater than the high one (3.2\% vs $1 \%, 13 \%$ vs $10 \%)$, while the number of stage I, III and IV cases were lower in patients with low educated group compared to the high educated one ( $21 \%$ vs $22.9 \%, 8.7 \%$ vs $12 \%$, $4.1 \%$ vs $5.6 \%$ ). Table 11 shows the correlation of low and high educational level and staging in 1015 cases of the nine most frequent cancers. The number of late stage cases (stage II-IV) in cervical cancer was higher in the lower educated group compared to the higher educated group (122 vs 55). The same comparison was found in lymph nodes (20 vs 8 ), skin (11 vs 10 ) and eye malignancies (21 vs 3 ). This condition might be related to the fact that a great number of patients had low level of education. Good education would contribute to a good knowledge about health care and to a greater chance for having a job. On the other hand, low educational level would result in unemploy- ment and low socio-economical status. Consequently, the health care including cancer screening would be neglected.

\section{The Most Valid Basis of Diagnosis of Cancer}

Table viii shows the most valid basis of diagnosis for selected sites, 1366 (63.7\%) cases were diagnosed by histopathology of primary tumor, 251 (11.7\%) by histopathology of metastases, 265 (12.4\%) were diagnosed by cytology/hematology, 72 (3.3\%) were diagnosed by clinical only, $173(8.1 \%)$ by clinical investigations (X-ray, USG etc), 11 (0.1\%) by exploratory surgery, and $6(0.03 \%)$ by bochemical or immunological test. Thus, there were $88 \%$ caes which were diagnosed by microscopic examinations and, in fact, was higher than in Singapore (76.4\%), ${ }^{11}$ and in the Phili/ipines $(52.5 \%$ in males and $63.2 \%$ in females). 
Table 11. Nine most frequent cancers by staging and educational level

\begin{tabular}{|c|c|c|c|c|c|c|c|c|c|c|c|c|}
\hline \multirow{2}{*}{ ICD-0 } & \multirow{2}{*}{ Description } & \multicolumn{2}{|c|}{ St-0 } & \multicolumn{2}{|c|}{ S1-I } & \multicolumn{2}{|c|}{ St-I! } & \multicolumn{2}{|c|}{ St-III } & \multicolumn{2}{|c|}{ St-IV } & \multirow{2}{*}{ Tomi } \\
\hline & & LEG* & $\mathrm{HEG}^{* *}$ & LEG & HEG & LEG & HEG & LEG & HEG & LEG & HEG & \\
\hline C539 & Cervix Uteri & 7 & 5 & 134 & 91 & 108 & 47 & 10 & 5 & 4 & 3 & 414 \\
\hline Cllo-119 & Nasopharynx & 0 & 0 & 2 & 4 & 4 & 12 & 50 & 74 & l & 3 & 150 \\
\hline C500-509 & Breast & & 3 & 13 & 45 & & 4 & 13 & 26 & 4 & 15 & 125 \\
\hline C180-218 & Colorectal & & 3 & 14 & 27 & 5 & 14 & 2 & 12 & 6 & IO & 94 \\
\hline C770-770 & Lymph nodes & 0 & 0 & 3 & l & 4 & 4 & 13 & 3 & 3 & 1 & 32 \\
\hline C2200 & Liver & 0 & 0 & 2 & 4 & 0 & 2 & 0 & 2 & 3 & & 14 \\
\hline C739 & Thyroid gland & 0 & 0 & 10 & 21 & 4 & & 5 & 10 & 3 & & 55 \\
\hline \multirow[t]{3}{*}{ C690-699 } & Eye & 3 & 2 & 14 & 7 & 13 & 2 & 4 & 0 & 4 & & 50 \\
\hline & Total & 16 & 14 & 226 & 221 & 148 & 92 & 99 & 136 & 28 & 35 & 1015 \\
\hline & Percentage & 1.6 & 1.4 & 22.3 & 22 & 15 & 9.1 & 9.8 & $13-4$ & 28 & 3.4 & 100 \\
\hline
\end{tabular}

* LEG $=$ Low educated group (illiterate, able to write and read, elementary)

** HEG $=$ High educated group (junior and senior high school, academy)

\section{Histological Types}

Table ix shows the number of cases in ten most frequent cancers by histological type. As the diagnosis of the hepatoma was merely made based on USG examination, it became exceptional and consequently, the ovarian cancer was chosen as tumor number ten. The most frequent histologic subtype of malignancies in cervic the was keratinizing squamous cell carcinoma (60.4\%), in nasoprahy was undifferentiated carcinoma (79\%), in the breast was invasive ductal carcinoma (58.1\%), in the bone marrow was acute lymphoblastic leukemia (50.3\%), in the colorectum was adenocarcinoma (68.4\%), in the skin was basal cell carcinoma (50\%), in the thyroid was papillary carcinoma (63.6\%) in eye was squamous cell carcinoma $(25.8 \%)$, and in the ovary was adenocarcinoma (35.6\%). This tabulation data can be used as guides on histological analytical study or for future research purposes. The number of squamous cell carcinoma in cervical cancer was significantly higher than adenocarcinoma of the cervix. In USA, the annual incidence of squamous carcinoma has been deelining steadily but adenocarcinoma has not. The decline might be related to the increased utilization of PAP smear, the improvement in vaginal hygiene, and changing sexual practices. ${ }^{25}$

\section{Initial Treatment}

The most frequent initial treatments among 1188 cancer patients was radiotherapy given to 339 (28.5\%) cases, followed by surgical treatment on 326 (27.4\%) cases, and chemotherapy on 117 (9.8\%) cases (table 12). These findings would bring a great burden to the department of radiotherapy and surgery. Good planning and effort should be made to prevent shortage in operating theaters and radiotherapy equipment.

Table 12. Nature of Initial Treatment on 1188 new cancer patients in 1998

\begin{tabular}{lcc}
\hline Treatment & Number & Percentage \\
Radiotherapy & 339 & 28.5 \\
Surgical treatment & 326 & 27.4 \\
Chemotherapy & 117 & 9.8 \\
Hormonal therapy & 11 & 0.9 \\
Combination & 8 & 0.7 \\
Immuno therapy & 385 & 32.4 \\
Total & 1188 & 100 \\
\hline
\end{tabular}

From figure 6, it can be seen than 491 (41\%) cases were treated within than 1 month, 29 (2\%) cases within 1 month, 11 (1\%) cases within 2 months, 3 $(0.2 \%)$ cases within 3 months and the delayed treatment consisted more than 4 months after diagnosis. There were also 602 (51\%) cases which were not known. The delayed treatment group and the not known status might be due to the poor socioeconomical condition of the patients, and it would increase the risk of treatment failure. 


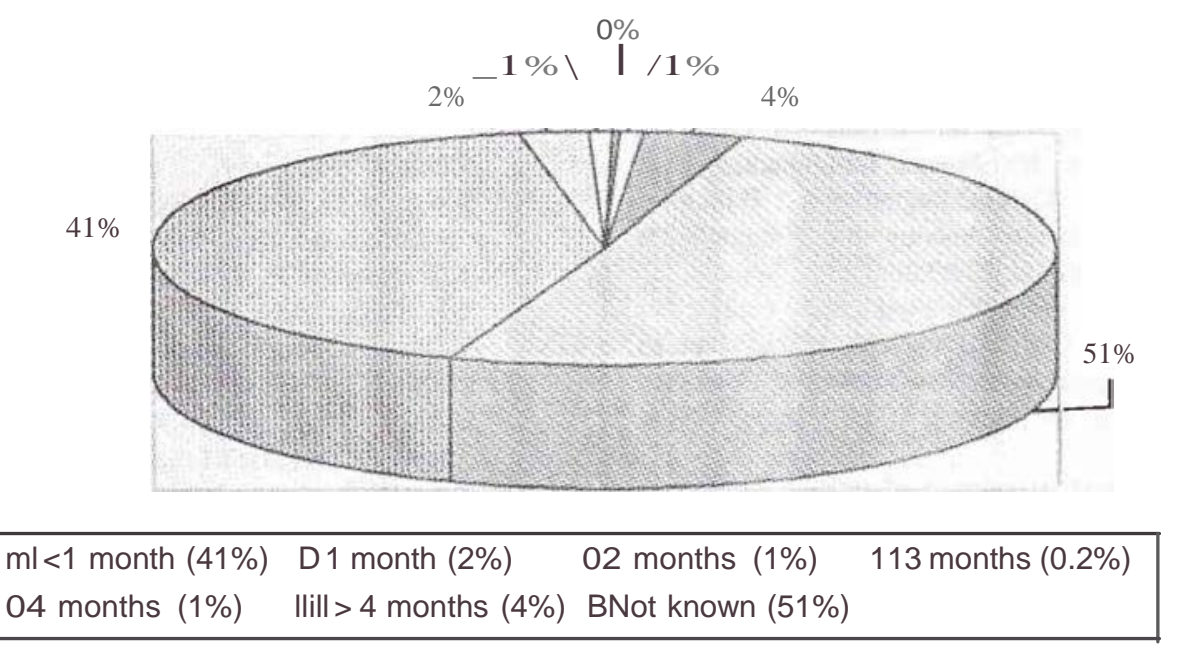

Figure 6. Time between the data of diagnosis and the initiation of cancer therapy

\section{CONCLUSION}

1. During the period of $1997-1998$ out of 444.178 patients of all patients treated in Cipto Mangunkusumo hospital were $2144(0.48 \%)$ cancer patients. The number of female patients was 1.7 times greater than the males.

2. The age peaked at 35-44 years in females, and at 45-54 years in males. In general, the mean age at diagnosis of various cancers was younger compared to other centers.

3. In females the most common malignancies were cervical, breast and nasopharyngeal cancers, while in males they were nasopharyngeal, bone marrow and liver cancers. In children the most common malignancies were acute lymphocytic leukemia, acute non-lymphocytic leukemia, retinoblastoma, nephroblastoma and non-Hodgkin's lymphoma.

4. The number of female patients with low educational level was greater than the male ones. Female patients with cervical, skin, bone marrow, ovary, lymph nodes malignancies and male patients with bone marrow, lymph nodes and eye malignancies had lower educational level.

5. The number of the late stage cancers in cervical, lymph nodes, skin and eye cancers was higher in lower educated group compared to $\mathrm{h}$ igher educated group.

6. The majority of patients (85\%) was diagnosed by microscopic examination. The number of the early stage cancers was lower compared to the late stage cancers (47\% vs 53\%).

7. The most frequent initial treatment given to cancer patients was radiotherapy, followed by surgery and chemotherapy.

8. In 1998, only $45 \%$ patients received treatments within 3 months after diagnosis.

\section{Acknowledgement}

The authors would like to thank Dr. Helmy Rustam MM, Dra. Sri Sulistyoningsih, and the staff of department of Medical Record, all doctors from the cancer treating departments in Cipto Mangunkusumo Hospital for their excellent care and data collection. Special thanks to Dr. Suzanna Ndraha SpPD and Mrs Maryati for their helps in data compu ting and secretarial works. This work was supported by Cipto Mangunkusumo National Center General Hospital (RSUPNCM) with the approval of the Dean, Faculty of Medicine, University of Indonesia, No. 30/SKB/FK/Ul/97, and was partially supported by the Indonesian Cancer Foundation.

\section{REFERENCES}

1. Ministry of Health of the Republic of Indonesia. Guidelines for Cancer Control in Indonesia, 1989. (in Indonesian).

2. Sukardja DG. The Organization of cancer in Indonesia, presented at the National Cancer Seminar II held by the Lembaga Kanker Indonesia in October, 1980. 
3. World Health Organization. WHO Handbook for Standardized Cancer Registries, Geneva 1976.

4. MacLennan R. Items of patient information which may be collected by registries. In: Jansen OM, Parkin DM; MacLennan R, Editors. Cancer Registration : Principles and Methods. International Agency for Researoh on Cancer, Lyon, France, 1991 : 43-63.

5. Muir CS, Percy C. Classification and coding of neoplasms. In: Jansen OM, Parkin DM, MacLennan R, Editors. Cancer Registration: Principles and Methods. International Agency for Research on Cancer, Lyon, France, 1991: 64-81.

6. Jensen OM, Storm HH. Reporting of results. In: Jansen OM, Parkin DM, MacLennan R, Editors. Cancer Registration: Principles and Methods. International Agency for Research on Cancer, Lyon, France, 1991: 10825.

7. Percy C, Holten VV, Muir C. International Classification of Diseases for Oncology. World Health Organization, Geneva, 1990.

8. Sitas F. National Cancer Registry of South Africa. Annual Statistical Report for 1988. South African Institute for Medical Research, Johannesburg 1992.

9. Sukardja IDG. Morbidity and mortality of cancer in Surabaya, Indonesia. In: Tjokronegoro A, Himawan S, Jusuf A, Susworo, Aziz MF, Djakaria M (eds). Cancer in Asia Pacific, vol 1, Yayasan Kanker Indonesia. Jakarta, $1988: 153-79$.

10. Partoatmodjo M, Rosfein R, Gunawan S. A survey on cancer in 17 hospitals in Jakarta. In: Tjokronegoro A, Himawan S, Jusuf A, Susworo, Aziz MF, Djakaria M (eds). Cancer in Asia Pacific, vol l, Yayasan Kanker Indonesia, Jakarta, 1988 : 181-94.

11. Lee HP, Day NE, Shanmugaratnarn K. Trends in Cancer Incidence in Singapore 1968-1982. International Agency for Research on Cancer, Lyon, 1988 : 20-1.

12. Laudico Ay, Esteban D, Parkin DM. Cancer in the Philippines. World Health Organization . International Agency for Research on Cancer, Lyon, 1989.

13. Hisamichi S. Cancer Registry in Japan. In: Tjokronegoro A, Himawan S, Jusuf A, Susworo, Aziz MF, Djakaria M (eds). Cancer in Asia Pacific, vol 1, Yayasan Kanker Indonesia, Jakarta, 1988:117-40.

14. Fowler J, Montz FJ. Malignancies of the Uterine Cervix. In: Cameron RB. Practical Oncology. Prentice Hall
International Inc., New Jersey 1994: 364-76.

15. Fisher B. Malignancies of the Breast. In: Cameron-RB. Practical Oncology, Prentice Hall International Inc., New Jersey 1994: 417-34.

16. Soetjipto D, Fachruddin D, Syafril A. Nasopharyngeal Carcinoma in Cipto Mangunkusumo General Hospital. In: Tjokronegoro A, Himawan S, Jusuf A, Susworo, Aziz MF, Djakaria M (eds). Cancer in Asia Pacific, vol 1, Yayasan Kanker Indonesia, Jakarta, 1988:499-513.

17. Luthra UK, Pabhakar AK, Ravi S. Cancer Registration in India. In: Tjokronegoro A, Himawan S, Jusuf A, Susworo, Aziz MF, Djakaria M (eds). Cancer in Asia Pacific, vol 1, Yayasan Kanker Indonesia, Jakarta, 1988 : 103-115.

18. Yanagawa $H$, Fujita $Y$, Nagai $M$, Nakamura $Y$, Noda $K$, Teshima K, et al. Comparative epidemiological study of cervical cancer between Japan and Indonesia. In: Sasaki R, Aoki K, Eds. Epidemiology and prevention of cancer. The University of Nagoya Press, 1990:84-96.

19. Ramli M. Budiningsih S, Ohno Y. Comparative study of the two-period of epidemiological analysis of risk factors for breast cancers in Indonesia. Does it change ? Med J lndones, 1999; 8:90-7.

20. Santana V. Childhood leukemia. In: Cameron RB. Practical Oncology. Prentice Hal International Inc., New Jersey $1994: 581$.

21. Priyanto. Eye cancer in Soetomo Hospital, Surabaya, Indonesia. In : Tjokronegoro A, Himawan S, Jusuf A, Susworo, Aziz MF, Djakaria M (eds). Cancer in Asia Pasific, vol 1; Yayasan Kanker Indonesia, Jakarta, 1988:437-41.

22. Mci ntosh JK, Cameron RB. Malignancies of the eye. In: Cameron RB. Practical Oncology. Prentice Hall International Inc., New Jersey 1994: 575-80.

23. Nord RG, Filmer RB. Wilms' tumor. In: Cameron RB Practical Oncology. Prentice Hall International Inc., New Jersey 1994: 593-8.

24. Santana V. Childhood lymphoma. In: Cameron RB. Practical Oncology. Prentice Hall International Inc., New Jersey 1994: 588-92.

25. Ross RK, Henderson BE, Peters R, Mack T. Epidemiology in relation to cancer control in the USA. In: Tjokronegoro A. Himawan S, Jusuf A, Susworo, Aziz MF, Djakaria M (eds). Cancer in Asia Pacific, vol l, Yayasan Kanker Indonesia, Jakarta, 1988: 23-36. 


\section{Appendix}

Table ia. Numbers of new cases by primary site and age in females

\begin{tabular}{|c|c|c|c|c|c|c|c|c|c|c|c|}
\hline ICD-0 & Description & $<5$ & $5-14$ & $15-24$ & $25-34$ & $35-44$ & $45-54$ & $55-64$ & $>65$ & Total & Rf \\
\hline C019 & Base of tongue & I & 0 & 0 & & 0 & 0 & & & 4 & 0.3 \\
\hline С020-029 & Oau parts of tongue & 0 & 0 & 0 & 2 & 3 & 6 & & & 13 & 0.97 \\
\hline C041-049 & Floor of mouth & 0 & 0 & & 0 & 0 & 0 & 0 & 0 & 1 & 0.07 \\
\hline C050-059 & Palate & 0 & & & 0 & & 2 & 3 & 0 & 8 & 0.59 \\
\hline C060-069 & Oau parts of mouth & 0 & 0 & & 0 & 0 & 2 & 0 & & 4 & 0.3 \\
\hline C070-079 & Parotid gland & 0 & & 1 & 0 & 2 & 0 & I & 0 & 5 & 0.37 \\
\hline C080-089 & Oau major salivary glands & 0 & 0 & 0 & 0 & 0 & 0 & & 0 & & 0.07 \\
\hline C090-099 & Tonsil & 0 & I & 1 & 0 & 0 & 0 & & 0 & 3 & 0.22 \\
\hline C100-109 & Oropahrynx & 0 & 0 & 0 & 0 & 0 & 0 & 0 & 0 & 0 & 0 \\
\hline Cllo-119 & Nasopharynx & 0 & & 5 & 7 & 20 & 21 & 7 & 2 & 63 & 4.68 \\
\hline Cl50-159 & Esophagus & 0 & 0 & 0 & 0 & 0 & 0 & $\mathbf{I}$ & & 2 & 0.15 \\
\hline C160-169 & Stomach & 0 & 0 & 2 & 0 & 0 & 0 & & 0 & 3 & 0.22 \\
\hline Cl70-179 & Small intestine & 0 & 0 & 0 & 0 & & 2 & & 0 & 4 & 0.3 \\
\hline Cl80-218 & Colorectal & 0 & 0 & 5 & 7 & 11 & 11 & 17 & 11 & 62 & 4.61 \\
\hline C220 & Liver & 0 & 0 & 0 & I & 4 & 2 & 11 & 2 & 20 & 1.49 \\
\hline C239 & Gall bladder & 0 & 0 & 0 & 0 & I & 0 & 0 & 0 & & 0.07 \\
\hline C241 & Arnpulla of Vater & 0 & 0 & 0 & $\mathbf{I}$ & 0 & 0 & 0 & 0 & & 0.07 \\
\hline C250 & Head of pancreas & 0 & 0 & 0 & 0 & 0 & I & 0 & 0 & & 0.07 \\
\hline C300 & Nasal cavity & 0 & I & I & 0 & 0 & 2 & 0 & 0 & 4 & 0.3 \\
\hline C310 & Maxillary sinus & 1 & 0 & & 1 & 0 & & 2 & 2 & 8 & 0.59 \\
\hline C340 & Bronchus and lung & 0 & 0 & $\mathbf{I}$ & 0 & 0 & 0 & & 3 & 5 & 0.37 \\
\hline C398 & $\begin{array}{l}\text { Overlap.lesion of resp. syst. and } \\
\text { intrathoracal organs }\end{array}$ & 0 & & 0 & 0 & 0 & 0 & 0 & 0 & & 0.07 \\
\hline C402 & Long bones of lower limb & & & & 0 & 0 & 0 & 0 & 0 & 3 & 0.22 \\
\hline C410-419 & $\begin{array}{l}\text { Bone, joint and a,rtilcular cartilage } \\
\text { of oau sites }\end{array}$ & 0 & & 0 & & 3 & & I & & 8 & 0.59 \\
\hline C421 & Bone marrow & 20 & 13 & 3 & 6 & 6 & 4 & 7 & 0 & 59 & 4.38 \\
\hline C424 & Hematopoietic system & 0 & 0 & 0 & 0 & 0 & 0 & 0 & 0 & 0 & 0 \\
\hline C440-449 & Skin & 1 & & 1 & 2 & 4 & 5 & 21 & 27 & 62 & 4.61 \\
\hline C480-482 & Retroperitoneurn and peritoneum & 2 & 0 & 0 & 1 & 0 & 2 & 0 & & 6 & 0.45 \\
\hline C490-499 & $\begin{array}{l}\text { Connective, subcutaneuous and } \\
\text { other soft tissues }\end{array}$ & 2 & 0 & 0 & & 0 & & 0 & 0 & 4 & 0.3 \\
\hline CS00-509 & Breast & 0 & 0 & 2 & 23 & 61 & 41 & 36 & 8 & 171 & 12.7 \\
\hline C510-519 & Vulva & 0 & 0 & 0 & & 3 & 3 & 3 & 3 & 13 & 0.97 \\
\hline C529 & Vagina & 0 & 0 & 0 & 1 & 7 & 5 & 6 & 4 & 23 & 1.71 \\
\hline C539 & Cervix uteri & 0 & 1 & & 33 & 164 & 150 & 94 & 39 & 482 & 35.8 \\
\hline C541-549 & Corpus uteri & 0 & 0 & 0 & 2 & 0 & 6 & 9 & 2 & 19 & 1.41 \\
\hline C559 & Uterus & 0 & 0 & 0 & 2 & 2 & 2 & & 1 & 8 & 0.59 \\
\hline C569 & Ovary & 0 & 2 & 8 & 10 & 18 & 8 & 10 & 3 & 59 & 4.38 \\
\hline C589 & Placenta & 0 & 0 & 7 & 21 & 8 & 0 & 0 & 0 & 36 & 2.67 \\
\hline C649 & Kidney & 3 & 6 & 0 & 2 & 0 & 0 & 1 & 0 & 12 & 0.89 \\
\hline C679 & Bladder & 0 & 0 & 0 & 2 & 4 & 0 & 0 & 2 & 8 & 0.59 \\
\hline С690-699 & Eye & 3 & 2 & 0 & 6 & 2 & 7 & 2 & 3 & 25 & 1.86 \\
\hline C700-709 & Meninges & 0 & 0 & 0 & 2 & 0 & 0 & 0 & 0 & 2 & 0.15 \\
\hline C710-719 & $\mathbf{B}$ & 0 & 2 & 1 & 0 & 1 & 2 & 1 & 0 & 7 & 0.52 \\
\hline C720-729 & $\begin{array}{l}\text { Spinal cord, cranial nerves, and } \\
\text { others parts of CNS }\end{array}$ & 3 & 2 & 0 & 0 & & 0 & 0 & 0 & 6 & 0.45 \\
\hline C730-739 & Thyroid gland & 0 & 0 & 4 & 19 & 16 & 11 & 9 & 4 & 63 & 4.68 \\
\hline C750-759 & $\begin{array}{l}\text { Others ehdocrine glands and } \\
\text { related structures }\end{array}$ & & 0 & & & 0 & 0 & 0 & 0 & 3 & 0.22 \\
\hline C760-768 & Other and illdefined sites , & 2 & 3 & 0 & $\mathbf{I}$ & & 0 & & 0 & 8 & 0.59 \\
\hline \multirow[t]{3}{*}{ C778-779 } & Lymph nodes & 2 & 2 & 3 & 6 & 16 & 8 & 7 & $\mathbf{I}$ & 45 & 3.34 \\
\hline & All sites & 42 & 42 & 52 & 163 & 360 & 306 & 258 & 123 & 1346 & 100 \\
\hline & Percentage & 3.1 & 3.1 & 3.9 & 12.1 & 26.7 & 22.7 & 19.2 & 9.1 & 100 & \\
\hline
\end{tabular}

Oau $=$ Others and Unspecified

CNS $=$ Central Nerves System

$\mathrm{Rf}=$ Relative frequency 
Table ib. Numbers of new cases by primary site and age in males

\begin{tabular}{|c|c|c|c|c|c|c|c|c|c|c|c|}
\hline ICD-0 & Description & $<5$ & $5-14$ & $15-24$ & $25-34$ & $35-44$ & $45-54$ & $55-64$ & $>65$ & Total & $\mathrm{Rf}$ \\
\hline C019 & Base of tongue & & 2 & 0 & I & & & & 0 & 5 & 0.63 \\
\hline C020-029 & Oau parts of tongue & 0 & $\odot$ & $\odot$ & 0 & & & 3 & 0 & 6 & 0.75 \\
\hline C041-049 & Floor of mouth & 0 & $\odot$ & $\odot$ & 0 & & & 0 & 0 & I & 0.13 \\
\hline C050-059 & Palate & 0 & $\odot$ & $\odot$ & 2 & & & 0 & 1 & 4 & 0.5 \\
\hline C060-069 & Oau parts of mouth & 0 & $\odot$ & $\odot$ & 0 & & & & 2 & 3 & 0.38 \\
\hline C070-079 & Parotid gland & 0 & $\odot$ & $\odot$ & 3 & & & I & 2 & 10 & 1.25 \\
\hline C080-089 & Oau major salivary glands & 0 & 0 & 0 & 0 & & & 0 & 0 & I & 0.13 \\
\hline C090-099 & Tonsil & 0 & $\odot$ & $\odot$ & 0 & & & I & & 5 & 0.63 \\
\hline Cl00-109 & Oropahrynx & 0 & $\odot$ & $\odot$ & 0 & & & $\odot$ & & 4 & 0.5 \\
\hline C $110-119$ & Nasopharynx & 0 & 5 & 11 & 16 & & & 20 & 9 & 132 & 16.5 \\
\hline Cl50-159 & Esophagus & 0 & $\odot$ & $\odot$ & 0 & & & 2 & 2 & 5 & 0.63 \\
\hline Cl60-169 & Stomach & 0 & $\odot$ & $\odot$ & 0 & & & 5 & 0 & 9 & 1.13 \\
\hline C $170-179$ & Small intestine & 0 & $\odot$ & $\odot$ & & & & 0 & I & 3 & 0.38 \\
\hline Cl80-218 & Colorectal & 0 & $\odot$ & $\odot$ & 12 & & & 14 & 6 & 52 & 6.52 \\
\hline C220 & Liver & 0 & I & 0 & 4 & & & 18 & 19 & 70 & 8.77 \\
\hline C239 & Gall bladder & 0 & $\odot$ & $\odot$ & 0 & & & 2 & I & 3 & 0.38 \\
\hline C241 & Ampulla of Yater & 0 & $\odot$ & $\odot$ & 0 & & & 0 & 0 & I & 0.13 \\
\hline C250 & Head of pancreas & 0 & 0 & & 0 & & & 4 & & 7 & 0.88 \\
\hline C300 & Nasal cavity & 0 & 0 & 2 & $\mathbf{I}$ & & & 3 & 2 & 8 & \\
\hline C310 & Maxillary sinus & 0 & 0 & $\mathbf{I}$ & 0 & & & 2 & 3 & 6 & 0.75 \\
\hline C340 & Bronchus and lung & 0 & $\odot$ & $\odot$ & 0 & & & 6 & 5 & 17 & 2.13 \\
\hline C398 & $\begin{array}{l}\text { Overlap.lesion of resp. syst. and } \\
\text { intrathoracal organs }\end{array}$ & 0 & $\odot$ & $\odot$ & 0 & & & & 0 & & 0.13 \\
\hline C402 & Long bones of lower limb & 0 & 2 & I & & 0 & & $\mathbf{I}$ & 0 & 6 & 0.75 \\
\hline C410-419 & $\begin{array}{l}\text { Bone, joint and artilcular cartilage of } \\
\text { oau sites }\end{array}$ & 0 & & 0 & & 0 & & 0 & $\mathbf{I}$ & 4 & 0.5 \\
\hline C421 & Bone marrow & 25 & 51 & 9 & 6 & 7 & 6 & 6 & 2 & 112 & 14 \\
\hline C424 & Hematopoietic system & 0 & $\mathbf{I}$ & 0 & 0 & 0 & 0 & 0 & 0 & I & 0.13 \\
\hline C440-449 & Skin & 2 & 0 & 0 & & 5 & 7 & 14 & 11 & 40 & 5.01 \\
\hline C480-482 & Retroperitoneum and peritoneum & & 0 & 0 & & I & 0 & I & & 5 & 0.63 \\
\hline C490-499 & $\begin{array}{l}\text { Connective, subcutaneuous and other } \\
\text { soft tissues }\end{array}$ & 2 & 3 & & 2 & 2 & 2 & 4 & 2 & 18 & 2.26 \\
\hline C500-509 & Breast & 0 & 0 & 0 & 0 & 0 & 0 & $\mathbf{I}$ & 0 & & 0.13 \\
\hline C609 & Penis & 0 & 0 & & 2 & 2 & 3 & 2 & 4 & 14 & 1.75 \\
\hline C619 & Prostate gland & 0 & 0 & 0 & 0 & 0 & 2 & 7 & 20 & 29 & 3.63 \\
\hline C629 & Descended testis & 2 & & $\mathbf{I}$ & 5 & 3 & 2 & 0 & 0 & 14 & 1.75 \\
\hline C649 & Kidney & 5 & & 0 & 3 & 2 & 2 & 3 & 2 & 18 & 2.26 \\
\hline C679 & Bladder & 0 & 0 & & 3 & 3 & 8 & 14 & 7 & 36 & 4.51 \\
\hline C690-699 & Eye & 9 & 7 & $\mathbf{I}$ & 0 & 3 & 6 & 7 & 4 & 37 & 4.64 \\
\hline C700-709 & Meninges & 0 & 0 & 0 & & $\mathbf{I}$ & 0 & 0 & $\odot$ & 2 & 0.25 \\
\hline C710-719 & Brain & 0 & 1 & 3 & I & 0 & 4 & 4 & 0 & 13 & 1.63 \\
\hline C720-729 & $\begin{array}{l}\text { Spinal cord, cranial nerves, and others } \\
\text { parts of CNS }\end{array}$ & 0 & 0 & 0 & 0 & 0 & 0 & & 0 & & 0.13 \\
\hline C730-739 & Thyroid gland & 0 & 0 & 2 & 3 & 2 & 2 & 4 & $\mathbf{I}$ & 14 & 1.75 \\
\hline$c^{75} \mathrm{O}^{-759}$ & $\begin{array}{l}\text { Others endocrine glands and related } \\
\text { structures }\end{array}$ & 0 & & 2 & I & 0 & & 0 & 0 & 5 & 0.63 \\
\hline C760-768 & Other and ill defined sites & 2 & $\mathbf{I}$ & $\mathbf{I}$ & I & & 3 & 2 & $\mathbf{I}$ & 12 & 1.5 \\
\hline C778-779 & Lymph nodes & 4 & 8 & 4 & 8 & 12 & 8 & II & 8 & 63 & 7.89 \\
\hline & All sites & 53 & 86 & 42 & 80 & 114 & 137 & 166 & 120 & 798 & 100 \\
\hline & Percentage & 6.6 & 10.8 & 5.3 & $\mathrm{IO}$ & 14.3 & 17.2 & 20.8 & 15 & 100 & \\
\hline
\end{tabular}

Oau $=$ Others and Unspecifjed

CNS $=$ Central Nerves System 
Table 11. Number of new cancer cases by primary sites and age

\begin{tabular}{|c|c|c|c|c|c|c|c|c|c|c|c|}
\hline ICD-0 & Description & $<5$ & $5-14$ & $15-24$ & $25-34$ & $35-44$ & $45-54$ & $55-64$ & $>65$ & Total & $\mathrm{Rf}$ \\
\hline C019 & Base of tongue & 2 & 2 & 0 & 2 & 0 & 0 & 2 & I & 9 & 0.42 \\
\hline C020-029 & Oau parts of tongue & 0 & 0 & 0 & 2 & 6 & 6 & 4 & I & 19 & 0.89 \\
\hline C041-049 & Floor of mouth & 0 & 0 & I & 0 & 0 & I & 0 & 0 & 2 & 0.09 \\
\hline C050-059 & Palate & 0 & I & I & 2 & 2 & 2 & 3 & I & 12 & 0.56 \\
\hline C060-069 & Oau parts of mouth & 0 & 0 & I & 0 & 0 & 2 & I & 3 & 7 & 0.33 \\
\hline C070-079 & Parotid gland & 0 & I & I & 3 & 5 & I & 2 & 2 & 15 & 0.7 \\
\hline C080-089 & Oau major salivary glands & 0 & 0 & 0 & 0 & I & 0 & I & 0 & 2 & 0.09 \\
\hline C090-099 & Tonsil & 0 & I & I & 0 & 0 & 3 & 2 & I & 8 & 0.37 \\
\hline CI00-109 & Oropahrynx & 0 & 0 & 0 & 0 & 3 & 0 & 0 & I & 4 & 0.19 \\
\hline CI 10-119 & Nasopharynx & 0 & 6 & 16 & 23 & 55 & 57 & 27 & II & 195 & 9.09 \\
\hline Cl50-159 & Esophagus & 0 & 0 & 0 & 0 & 0 & I & 3 & 3 & 7 & 0.33 \\
\hline C 160-169 & Stomach & 0 & 0 & 2 & 0 & 2 & 2 & 6 & 0 & 12 & 0.56 \\
\hline Cl70-179 & Small intestine & 0 & 0 & 0 & I & 2 & 2 & I & I & 7 & 0.33 \\
\hline Cl80-218 & Colorectal & 0 & 0 & 5 & 19 & 21 & 21 & 31 & 17 & 114 & 5.32 \\
\hline $\mathrm{C} 220$ & Liver & 0 & I & 0 & 5 & 14 & 20 & 29 & 21 & 90 & 4.2 \\
\hline C239 & Gall bladder & 0 & 0 & 0 & 0 & 1 & 0 & 2 & 1 & 4 & 0.19 \\
\hline C241 & Ampulla of Vater & 0 & 0 & 0 & $\mathbf{I}$ & 0 & I & 0 & 0 & 2 & 0.09 \\
\hline $\mathrm{C} 250$ & Head of pancreas & 0 & 0 & I & 0 & 0 & 2 & 4 & $\mathbf{I}$ & 8 & 0.37 \\
\hline C300 & Nasal cavity & 0 & I & 3 & 1 & 0 & 2 & 3 & 2 & 12 & 0.56 \\
\hline C310 & Maxillary sinus & 1 & 0 & 2 & 1 & 0 & 1 & 4 & 5 & 14 & 0.65 \\
\hline C340 & Bronchus and lung & 0 & 0 & $\mathbf{I}$ & 0 & 1 & 5 & 7 & 8 & 22 & 1.03 \\
\hline C398 & Overlap.lesion of resp. syst. and intrathor. organs & 0 & $\mathbf{I}$ & 0 & 0 & 0 & 0 & & 0 & 2 & O.Q9 \\
\hline C402 & Long bones of lower limb & $\mathbf{I}$ & 3 & 2 & $\mathbf{I}$ & 0 & 1 & & 0 & 9 & 0.42 \\
\hline C410-419 & Bone, joint and artilcular cartilage of oau sites & 0 & 2 & 0 & 2 & 3 & 2 & $\mathbf{I}$ & 2 & 12 & 0.56 \\
\hline C421 & Bone marrow & 45 & 64 & 12 & 12 & 13 & 10 & 13 & 2 & 171 & 7.98 \\
\hline C424 & Hematopoietic system & 0 & $\mathbf{I}$ & 0 & 0 & 0 & 0 & 0 & 0 & 1 & 0.05 \\
\hline C440-449 & Skin & 3 & $\mathbf{I}$ & 1 & 3 & 9 & 12 & 35 & 38 & 102 & 4.76 \\
\hline C480-482 & Retroperitoneum and peritoneum & 3 & 0 & 0 & 2 & $\mathbf{I}$ & 2 & $\mathbf{I}$ & 2 & I I & 0.51 \\
\hline C490-499 & Connective, subcutaneuous and other soft tissues & 4 & 3 & 1 & 3 & 2 & 3 & 4 & 2 & 22 & 1.03 \\
\hline C500-509 & Breast & 0 & 0 & 2 & 23 & 61 & 41 & 37 & 8 & 172 & 8.02 \\
\hline C510-519 & Vulva & 0 & 0 & 0 & 1 & 3 & 3 & 3 & 3 & 13 & 0.61 \\
\hline C529 & Vagina & 0 & 0 & 0 & I & 7 & 5 & 6 & 4 & 23 & 1.07 \\
\hline C539 & Cervix uteri & 0 & I & I & 33 & 164 & 150 & 94 & 39 & 482 & 22.48 \\
\hline C541-549 & Corpus uteri & 0 & 0 & 0 & 2 & 0 & 6 & 9 & 2 & 19 & 0.89 \\
\hline C559 & Uterus & 0 & 0 & 0 & 2 & 2 & 2 & 1 & & 8 & 0.37 \\
\hline C569 & Ovary & 0 & 2 & 8 & 10 & 18 & 8 & 10 & 3 & 59 & 2.75 \\
\hline C589 & Placenta & 0 & 0 & 7 & 21 & 8 & 0 & 0 & 0 & 36 & 1.68 \\
\hline C609 & Penis & 0 & 0 & I & 2 & 2 & 3 & 2 & 4 & 14 & 0.65 \\
\hline C619 & Prostate gland & 0 & 0 & 0 & 0 & 0 & 2 & 7 & 20 & 29 & 1.35 \\
\hline C629 & Descended testis & 2 & I & $\mathbf{I}$ & 5 & 3 & 2 & 0 & 0 & 14 & 0.65 \\
\hline C649 & Kidney & 8 & 7 & 0 & 5 & 2 & 2 & 4 & 2 & 30 & 1.4 \\
\hline C679 & Bladder & 0 & 0 & I & 5 & 7 & 8 & 14 & 9 & 44 & 2.05 \\
\hline C690-699 & Eye & 12 & 9 & I & 6 & 5 & 13 & 9 & 7 & 62 & 2.89 \\
\hline C700-709 & Meninges & 0 & 0 & 0 & 3 & & 0 & 0 & 0 & 4 & 0.19 \\
\hline C710-719 & Brain & 0 & 3 & 4 & I & & 6 & 5 & 0 & 20 & 0.93 \\
\hline C720-729 & Spinal cord, cranial nerves, and others parts of CNS & 3 & 2 & 0 & 0 & $\mathbf{I}$ & 0 & $\mathbf{I}$ & 0 & 7 & 0.33 \\
\hline C730-739 & Thyroid gland & 0 & 0 & 6 & 22 & 18 & 13 & 13 & 5 & 77 & 3.59 \\
\hline C750-759 & Others endocrine glands and related structures & $\mathbf{I}$ & I & 3 & 2 & 0 & 1 & 0 & 0 & 8 & 0.37 \\
\hline C760-768 & Other and ill defined sites & 4 & 4 & I & 2 & 2 & 3 & 3 & I & 20 & 0.93 \\
\hline \multirow[t]{3}{*}{ C778-779 } & Lymph nodes & 6 & 10 & 7 & 14 & 28 & 16 & 18 & 9 & 108 & 5.04 \\
\hline & All sites & 95 & 128 & 94 & 243 & 474 & 443 & 424 & 243 & 2144 & 100 \\
\hline & Percentage & 4.43 & 5.97 & 4.38 & 11.3 & 22.1 & 20.7 & 19.8 & II & 100 & \\
\hline
\end{tabular}

Oau $=$ Others and Unspecified

CNS $=$ Central nervous system 
Table iii. Numbers of new cases by primary site and age in children

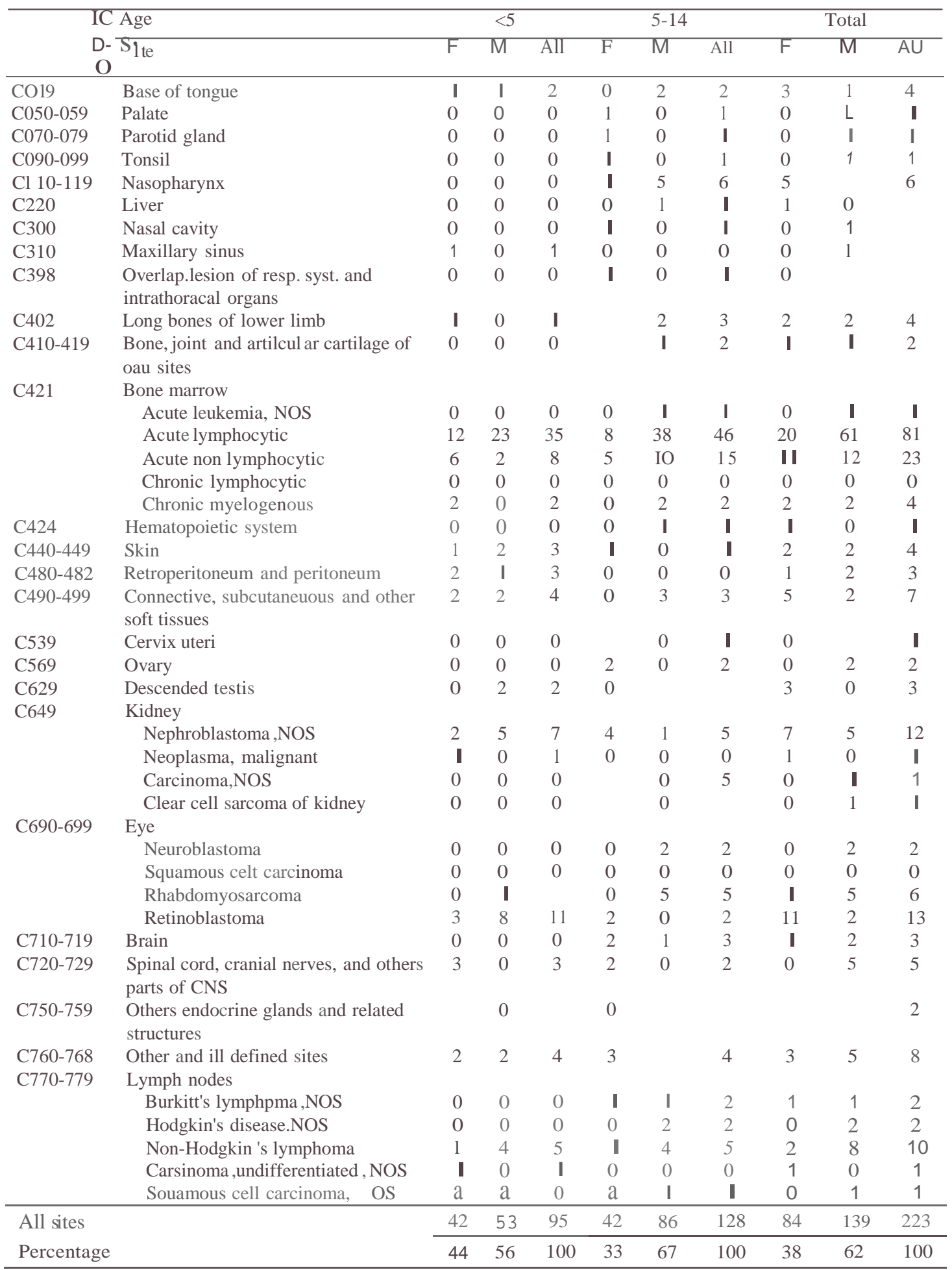


Table iv. Numbers of new cases by primary site and education in females

\begin{tabular}{|c|c|c|c|c|c|c|c|c|c|}
\hline ICD-0 & Description & & A & $\mathrm{E}$ & $\mathrm{JH}$ & SH & Ac & NK & Total \\
\hline C019 & Base of tongue & l & 0 & 0 & I & I & 0 & I & 4 \\
\hline C020-029 & Oau parts of tongue & 0 & l & 6 & 2 & 3 & l & 0 & 13 \\
\hline C04l-049 & Floor of mouth & 0 & 0 & I & 0 & 0 & 0 & 0 & l \\
\hline C050-059 & Palate & 2 & l & 0 & 4 & l & 0 & 0 & 8 \\
\hline C060-069 & Oau parts of mouth & 2 & l & 0 & 0 & I & 0 & 0 & 4 \\
\hline C070-079 & Parotid gland & 0 & 0 & l & 2 & l & 0 & l & 5 \\
\hline C080-089 & Oau major salivary glands & l & 0 & 0 & 0 & 0 & 0 & 0 & $\mathbf{I}$ \\
\hline C090-099 & Tonsil & 0 & 0 & l & I & l & 0 & 0 & 3 \\
\hline Cl00-109 & Oropahrynx & 0 & 0 & 0 & 0 & 0 & 0 & 0 & 0 \\
\hline Cllo-119 & Nasopharynx & 4 & 5 & 16 & 8 & 17 & 2 & II & 63 \\
\hline C150-159 & Esophagus & 0 & I & 0 & 0 & 0 & 0 & I & 2 \\
\hline C160-169 & Stomach & 0 & 0 & l & 0 & 2 & 0 & 0 & 3 \\
\hline CI70-179 & Small intestine & 0 & 0 & 1 & 2 & I & 0 & 0 & 4 \\
\hline Cl80-218 & Colorectal & 8 & 2 & 12 & 10 & 21 & 6 & 3 & 62 \\
\hline C220 & Liver & 3 & I & l & 2 & 3 & 0 & IO & 20 \\
\hline C239 & Gall bladder & 0 & 0 & 0 & 0 & 1 & 0 & 0 & l \\
\hline C241 & Ampulla of Yater & 0 & 0 & 0 & 0 & 0 & 0 & 1 & I \\
\hline C250 & Head of pancreas & 0 & 1 & 0 & 0 & 0 & 0 & 0 & 1 \\
\hline C300 & Nasal cavity & 0 & 0 & 2 & 0 & 0 & 0 & 2 & 4 \\
\hline C310 & Maxillary sinus & 2 & 0 & 2 & 0 & I & 0 & 3 & 8 \\
\hline C340 & Bronchus and lung & 0 & 0 & I & 0 & I & 2 & $\mathbf{I}$ & 5 \\
\hline C398 & $\begin{array}{l}\text { Overlap.lesion of resp. syst. and } \\
\text { intrathoracal organs }\end{array}$ & 1 & 0 & 0 & 0 & 0 & 0 & 0 & I \\
\hline C402 & Long bones of lower limb & 0 & & 1 & I & 0 & 0 & 0 & 3 \\
\hline C410-419 & $\begin{array}{l}\text { Bone,joint and artilcular cartilage } \\
\text { of oau sites }\end{array}$ & 0 & & 2 & 0 & 3 & I & 1 & 8 \\
\hline C421 & Bone marrow & 20 & 4 & 6 & 2 & 4 & 0 & 23 & 59 \\
\hline C424 & Hematopoietic system & 0 & 0 & 0 & 0 & 0 & 0 & 0 & 0 \\
\hline C440-449 & Skin & 17 & 6 & 17 & 7 & 8 & 0 & 7 & 62 \\
\hline C480-482 & Retroperitoneum and peritoneum & 2 & I & 0 & 0 & 3 & 0 & 0 & 6 \\
\hline C490-499 & $\begin{array}{l}\text { Connective, subcutaneuous and } \\
\text { other soft tissues }\end{array}$ & 0 & 1 & $\mathbf{I}$ & $\mathbf{I}$ & $\mathbf{I}$ & 0 & 0 & 4 \\
\hline C500-509 & Breast & 5 & 5 & 25 & 24 & 59 & 11 & 42 & 171 \\
\hline C510-519 & Vulva & 4 & I & I & 3 & 2 & I & 1 & 13 \\
\hline C529 & Vagina & 6 & 3 & 2 & 5 & 5 & I & I & 23 \\
\hline C539 & Cervix uteri & 73 & 89 & 129 & 79 & 75 & 10 & 27 & 482 \\
\hline C541-549 & Corpusuteri & I & 2 & 6 & 4 & $\mathbf{I}$ & I & 4 & 19 \\
\hline C559 & Uterus & 1 & 2 & 2 & I & $\mathbf{I}$ & 0 & I & 8 \\
\hline C569 & Ovary & 9 & 9 & 13 & 8 & 13 & 4 & 3 & 59 \\
\hline C589 & Placenta & 2 & 4 & 4 & 9 & 14 & 3 & 0 & 36 \\
\hline C649 & Kidney & 7 & 3 & 0 & I & 0 & 0 & 1 & 12 \\
\hline C679 & Bladder & 0 & 0 & 4 & I & 0 & 3 & 0 & 8 \\
\hline C690-699 & Eye & 13 & I & 5 & 3 & I & 0 & 2 & 25 \\
\hline C700-709 & Meninges & 0 & 0 & $\mathbf{I}$ & 0 & I & 0 & .0 & 2 \\
\hline C710-719 & Brain & l & 0 & 2 & I & $\mathbf{I}$ & l & I & 7 \\
\hline C720-729 & $\begin{array}{l}\text { Spinal cord, cranial nerves, and } \\
\text { others parts of CNS }\end{array}$ & 3 & I & I & l & 0 & 0 & 0 & 6 \\
\hline C730-739 & Thyroid gland & 4 & 4 & 13 & 3 & 18 & 4 & 17 & 63 \\
\hline C750-759 & $\begin{array}{l}\text { Others endocrine glands and } \\
\text { related structures }\end{array}$ & 1 & 0 & 0 & 0 & 2 & 0 & 0 & 3 \\
\hline C760-768 & Other and illdefined sites & 5 & 0 & l & I & 0 & 0 & $\mathbf{I}$ & 8 \\
\hline \multirow[t]{4}{*}{ C778-779 } & L)'.m[!h nodes & $\mathbf{I}$ & 1 & II & 2 & 4 & 0 & 26 & 45 \\
\hline & All sites & 199 & 152 & 292 & 189 & 271 & 51 & 192 & 1346 \\
\hline & Percentage & 15 & 11.3 & 21.7 & 14 & 20 & 3.8 & 14.3 & 100 \\
\hline & $\begin{array}{l}\text { €Illiterate } \\
\mathrm{A}=\text { Able to read and write } \\
\mathrm{E}=\text { Elementary }\end{array}$ & & & & $\begin{array}{l}\mathrm{IH}=\mathrm{Jur} \\
\mathrm{SH}=\mathrm{Se} \\
\mathrm{AC}=\mathrm{Ac} \\
\mathrm{NK}=\mathrm{No}\end{array}$ & $\begin{array}{l}\text { or Higl } \\
\text { or Hig } \\
\text { demy/l }\end{array}$ & $\begin{array}{l}\text { chool } \\
\text { chool } \\
\text { iversity }\end{array}$ & & \\
\hline
\end{tabular}


Table v. Numbers of new cases by primary site and education in males

\begin{tabular}{|c|c|c|c|c|c|c|c|c|c|}
\hline ICD-0 & Description & & A & $\mathrm{B}$ & $\mathrm{JH}$ & $\mathrm{SH}$ & Ac & NK & Total \\
\hline$\overline{\mathrm{C} 019}$ & Base of tongue & 3 & 1 & 0 & 0 & 0 & & 0 & 5 \\
\hline C020-029 & Oau parts of tongue & 0 & 0 & 2 & 2 & & & 0 & 6 \\
\hline C041-049 & Aoor of mouth & 0 & 0 & 0 & 0 & & 0 & 0 & \\
\hline C050-059 & Palate & 0 & 0 & 2 & 0 & 2 & 0 & 0 & 4 \\
\hline C060-069 & Oau parts of mouth & 0 & 0 & & $\mathbf{I}$ & $\mathbf{I}$ & 0 & 0 & 3 \\
\hline C070-079 & Parotid Gland & 0 & 0 & 2 & 0 & 3 & 3 & 2 & 10 \\
\hline C080-089 & Oau major salivary glands & 0 & 0 & 0 & 0 & 0 & I & 0 & I \\
\hline C090-099 & Tonsil & 0 & 0 & 2 & 1 & 0 & & I & 5 \\
\hline Cl00-109 & Oropahrynx & 0 & 0 & 2 & & I & 0 & 0 & 4 \\
\hline CII0-119 & Nasopharynx & 5 & 4 & 27 & 21 & 39 & 14 & 22 & 132 \\
\hline Cl50-159 & Esophagus & 0 & 0 & 0 & 2 & & $\mathbf{I}$ & I & 5 \\
\hline Cl60-169 & Stomach & 0 & 1 & 1 & 0 & 4 & 3 & 0 & 9 \\
\hline Cl70-179 & Small intestine & 0 & 0 & 0 & & 2 & 0 & 0 & 3 \\
\hline C180-218 & Colorectal & 0 & 5 & 9 & 12 & 18 & 4 & 4 & 52 \\
\hline C220 & Liver & 4 & $\mathbf{I}$ & 8 & 7 & 16 & 10 & 24 & 70 \\
\hline C239 & Gall bladder & 0 & 0 & 0 & 0 & I & 2 & 0 & 3 \\
\hline C241 & Ampulla of Yater & 0 & 0 & 0 & 0 & 0 & $\mathbf{I}$ & 0 & $\mathbf{I}$ \\
\hline $\mathrm{C} 250$ & Head of pancreas & 0 & 0 & 2 & & 2 & & & 7 \\
\hline C300 & Nasal cavity & 0 & & 5 & 0 & 0 & $\mathbf{I}$ & & 8 \\
\hline C310 & Maxillary sinus & 0 & 0 & 2 & 0 & 2 & 0 & 2 & 6 \\
\hline C340 & Bronchus and lung & 0 & 0 & 3 & 0 & 8 & 3 & '.3 & 17 \\
\hline C398 & $\begin{array}{l}\text { Overlap.lesion of resp. syst. } \\
\text { and intrathoracal organs }\end{array}$ & 0 & 0 & 0 & & 0 & 0 & 0 & \\
\hline C402 & Long bones of lower limb & 0 & 0 & 2 & 2 & 2 & 0 & 0 & 6 \\
\hline C410-419 & $\begin{array}{l}\text { Bone, joint and artilcular } \\
\text { cartilage of oau sites }\end{array}$ & & 0 & 0 & 0 & & 2 & 0 & 4 \\
\hline C421 & Bone marrow & 30 & 14 & 22 & 9 & 5 & & 31 & I12 \\
\hline $\mathrm{C} 424$ & Hematopoietic system & 0 & 0 & 0 & 0 & 0 & 0 & I & $\mathbf{I}$ \\
\hline C440-449 & Skin & 4 & 5 & 7 & 6 & J I & 5 & 2 & 40 \\
\hline C480-482 & $\begin{array}{l}\text { Retroperitoneum and } \\
\text { peritoneum }\end{array}$ & & & & 0 & 1 & & 0 & 5 \\
\hline C490-499 & $\begin{array}{l}\text { Connective, subcutaneuous } \\
\text { and other soft tissues }\end{array}$ & & 2 & 2 & 2 & 5 & & 5 & 18 \\
\hline C500-509 & Breast & 0 & 0 & 0 & 0 & $\mathbf{I}$ & 0 & 0 & $\mathbf{I}$ \\
\hline C609 & Penis & 0 & $\mathbf{I}$ & 4 & 3 & 5 & 0 & $\mathbf{I}$ & 14 \\
\hline C619 & Prostate gland & & 2 & 8 & 0 & 8 & 10 & 0 & 29 \\
\hline C629 & Descended testis & 2 & 0 & 3 & 3 & 6 & 0 & 0 & 14 \\
\hline C649 & Kidney & 4 & 0 & $\mathbf{I}$ & 0 & 8 & 4 & & 18 \\
\hline C679 & Bladder & & 3 & 8 & 6 & II & 6 & & 36 \\
\hline C690-699 & Eye & 17 & 7 & 2 & 4 & 4 & & 2 & 37 \\
\hline C700-709 & Meninges & 0 & 0 & 0 & 0 & 0 & & & 2 \\
\hline C710-719 & Brain & 1 & & & 3 & 3 & & 3 & 13 \\
\hline C720-729 & $\begin{array}{l}\text { Spinal cord, cranial nerves, } \\
\text { and others parts of CNS }\end{array}$ & 0 & 0 & 0 & 0 & $\mathbf{I}$ & 0 & 0 & $\mathbf{I}$ \\
\hline C730-739 & Thyroid gland & & 0 & 0 & 3 & 5 & 3 & 2 & 14 \\
\hline C750-759 & $\begin{array}{l}\text { Others endocrine glands and } \\
\text { related structures }\end{array}$ & & 0 & 0 & 0 & 2 & & & 5 \\
\hline C760-768 & Other and illdefined sites & 3 & 2 & 2 & 2 & & & $\mathbf{I}$ & 12 \\
\hline \multirow[t]{4}{*}{ C778-779 } & Lymph nodes & 6 & 2 & I I & 5 & 9 & 2 & 28 & 63 \\
\hline & All sites & 86 & 53 & 142 & 98 & 191 & 87 & 141 & 798 \\
\hline & Percentage & 10.8 & 6.64 & 18 & 12 & 23.9 & 10.9 & 17.67 & J00 \\
\hline & $\begin{array}{l}\mathrm{I}=\text { Illiterate } \\
\mathrm{A}=\text { Able to read and write } \\
\mathrm{E}=\text { Elementary }\end{array}$ & & & $\begin{array}{l}\mathrm{JH}=\mathrm{Jul} \\
\mathrm{SH}=\mathrm{Sel} \\
\mathrm{Ac}=\mathrm{Ac} \\
\mathrm{NK}=\mathrm{Nc}\end{array}$ & $\begin{array}{l}\mathrm{r} \text { High } \\
\mathrm{H} \text { High } \\
\text { my/U } \\
\text { Known }\end{array}$ & $\begin{array}{l}\text { chool } \\
\text { chool } \\
\text { versity }\end{array}$ & & & \\
\hline
\end{tabular}


Table vi. Numbers of new cases by primary site and staging in 1617 cases

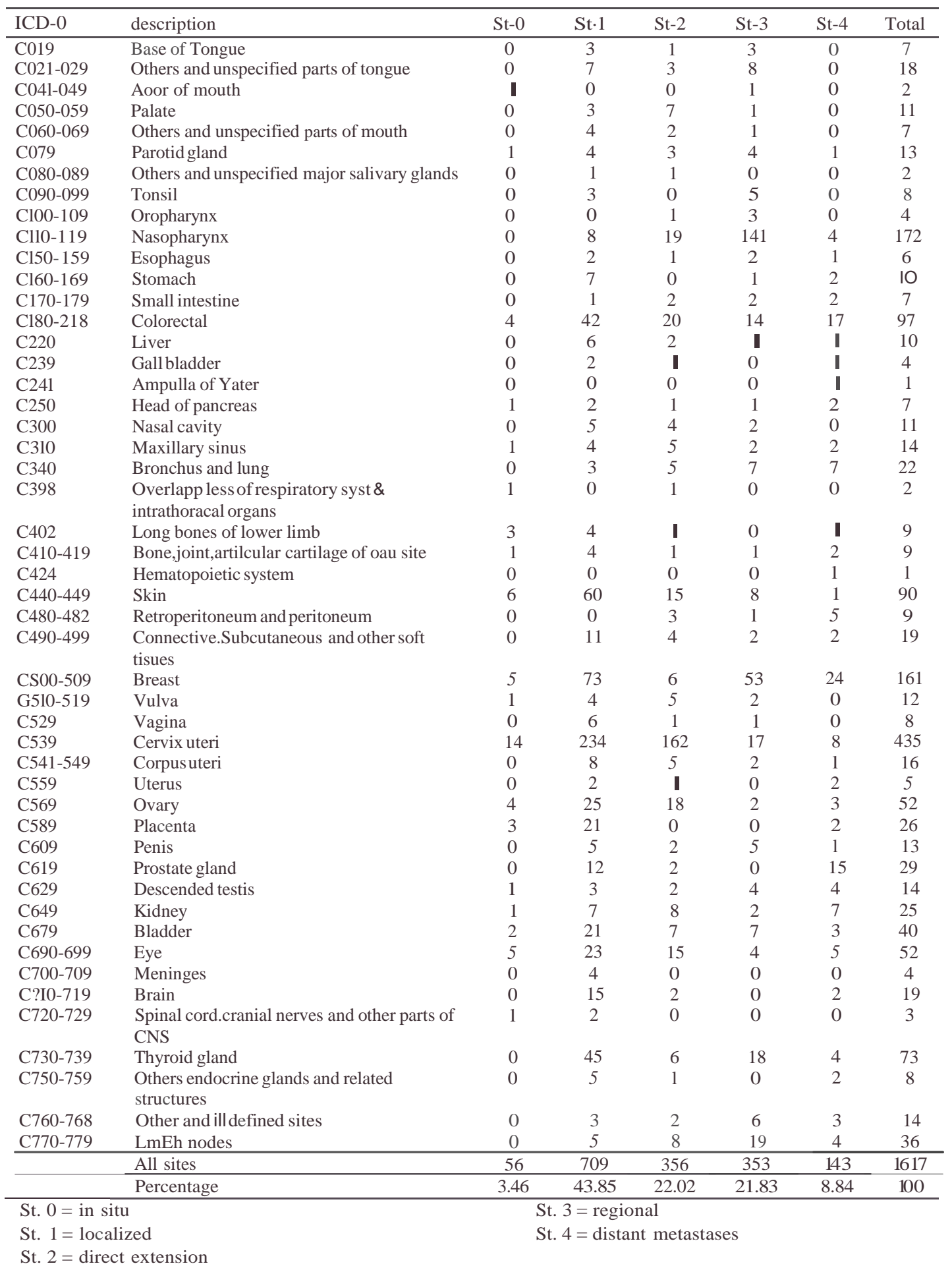

Bone marrow was excluded, as it consisted of 131 cases of acute and 24 chronic leukemia, 1 leukemia NOS, 6 cases of multiple myeloma, 6 cases of polycythemia vera, 3 other cases 
Tabel vii. Numbers of new cases by primary site, education and staging in 1484 cases

\begin{tabular}{|c|c|c|c|c|c|c|c|c|c|c|c|c|c|c|c|c|c|c|c|c|c|c|c|c|c|c|c|c|c|c|c|c|}
\hline \multirow{2}{*}{\multicolumn{3}{|c|}{ ICD-0 Description }} & \multicolumn{4}{|c|}{ StageO } & \multicolumn{8}{|c|}{$\underline{\text { Stage I }}$} & \multicolumn{6}{|c|}{$\underline{\text { Stage } \mathrm{n}}$} & \multicolumn{5}{|c|}{ tagc m } & \multicolumn{5}{|c|}{ JV } & & Total \\
\hline & & & A & $\mathrm{E}$ & $\mathrm{J}$ & S & Ac & & $\mathrm{A}$ & $\bar{E}$ & $\bar{J}$ & $\mathrm{~S} \mathrm{~A}$ & $A<$ & 1 & $\mathrm{~A}$ & $E$ & $\mathrm{~J}$ & $\mathrm{~S}$ & Ac & & $\mathrm{A}$ & $\mathrm{E}$ & $\mathrm{J}$ & $\mathrm{S}$ & Ac & 1 & A & $\mathrm{E}$ & $\mathrm{J}$ & S & Ac & \\
\hline COi 9 & Base of tongue & 0 & $\odot$ & 0 & 0 & 0 & 0 & 2 & 0 & 0 & & $0 \quad 0$ & 0 & 0 & 0 & $\theta$ & 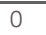 & 0 & 0 & & 0 & 0 & 0 & 1 & l & 0 & 0 & 0 & 0 & 0 & 0 & 6 \\
\hline C021-029 & Oau parts of tongue & 0 & 0 & 0 & 0 & 0 & 0 & 0 & 0 & 3 & I & 3 & 0 & 0 & 0 & I & I & 0 & l & 0 & I & 4 & 2 & 1 & 0 & 0 & $\odot$ & $\odot$ & $\odot$ & $\odot$ & $\odot$ & 18 \\
\hline C04l-049 & Floor of mouth & 0 & 0 & l & 0 & 0 & 0 & 0 & 0 & 0 & 0 & 0 & 0 & 0 & 0 & $\odot$ & $\odot$ & 0 & 0 & 0 & 0 & 0 & 0 & I & 0 & 0 & 0 & 0 & 0 & 0 & 0 & 2 \\
\hline C050-059 & Palate & 0 & 0 & 0 & 0 & 0 & 0 & 0 & 0 & 1 & 2 & 0 & 0 & 2 & 0 & 1 & 2 & 2 & $\odot$ & 0 & 0 & 0 & 0 & 1 & 0 & 0 & 0 & 0 & 0 & 0 & 0 & II \\
\hline C060-069 & Oau parts of mouth & $\odot$ & $\odot$ & $\odot$ & $\odot$ & $\odot$ & $\odot$ & 2 & 0 & l & 0 & 1 & 0 & 0 & 0 & 0 & 0 & & I & 0 & l & 0 & 0 & 0 & 0 & 0 & 0 & 0 & 0 & 0 & 0 & 7 \\
\hline C079 & Parotid gland & 0 & 0 & 0 & 0 & l & 0 & 0 & 0 & 0 & I & 1 & 1 & 0 & 0 & I & I & 1 & 0 & 0 & 0 & 2 & 1 & 1 & 0 & 0 & 0 & 0 & 0 & 0 & 0 & 11 \\
\hline C080.089 & Oau maj. salivary gl. & 0 & 0 & 0 & 0 & 0 & 0 & 0 & 0 & 0 & 0 & 0 & I & I & 0 & $\odot$ & $\odot$ & $\odot$ & $\odot$ & 0 & 0 & 0 & 0 & 0 & 0 & 0 & 0 & 0 & 0 & 0 & 0 & 2 \\
\hline C090-99 & Tonsil & 0 & 0 & 0 & 0 & 0 & 0 & 0 & 0 & 0 & l & 1 & 0 & 0 & 0 & $\odot$ & $\odot$ & $\odot$ & $\odot$ & 0 & 0 & 3 & & 0 & l & 0 & 0 & 0 & 0 & 0 & 0 & 7 \\
\hline Cl00-109 & Oropahrynx & 0 & 0 & 0 & 0 & 0 & 0 & 0 & 0 & 0 & 0 & 0 & 0 & 0 & 0 & 1 & 0 & $\odot$ & $\odot$ & 0 & 0 & l & & I & 0 & 0 & 0 & 0 & 0 & 0 & 0 & 4 \\
\hline C II0-119 I & Nasop & 0 & 0 & 0 & 0 & 0 & 0 & 0 & 0 & 2 & l & 21 & 1 & 1 & 2 & 1 & 4 & 5 & 3 & 8 & 7 & 35 & 21 & 42 & 11 & 0 & 0 & I & I & 2 & 0 & 150 \\
\hline Cl50-159 & Esophagus & 0 & 0 & 0 & 0 & 0 & 0 & 0 & 0 & 0 & 0 & $0 \quad 0$ & 0 & 0 & 1 & $\odot$ & $\odot$ & $\odot$ & $\odot$ & 0 & 0 & 0 & I & 1 & 0 & 0 & 0 & 0 & 1 & 0 & 0 & 4 \\
\hline Cl60-169 & Stomach & $\odot$ & $\odot$ & $\odot$ & $\odot$ & $\odot$ & $\odot$ & $\odot$ & $\odot$ & I & 0 & 42 & 2 & 0 & 0 & $\odot$ & $\odot$ & $\odot$ & $\odot$ & 0 & 0 & l & 0 & 0 & 0 & 0 & 0 & 0 & 0 & I & l & 10 \\
\hline $\mathrm{Cl} 70-179$ & Small intestine & 0 & 0 & 0 & 0 & 0 & 0 & 0 & l & 0 & 0 & $0 \quad \mathrm{c}$ & 0 & 0 & 0 & 0 & I & I & 0 & 0 & 0 & 0 & I & l & 0 & 0 & 0 & $\mathbf{I}$ & l & 0 & 0 & 7 \\
\hline Cl80-218 & Colorectal & 0 & 1 & 0 & 2 & I & 0 & 5 & 4 & 5 & 9 & 144 & 4 & 2 & 0 & 3 & 2 & 12 & 0 & 0 & 0 & 2 & 3 & 6 & 3 & 0 & 0 & 6 & 3 & 4 & 3 & 94 \\
\hline C220 & Liver & 0 & 0 & 0 & 0 & 0 & 0 & l & 0 & $\mathrm{r}$ & 2 & 2 & 0 & 0 & 0 & 0 & 0 & 2 & $\odot$ & 0 & 0 & 0 & 0 & l & l & l & 1 & I & l & 0 & 0 & 14 \\
\hline C239 & Gall bladder & 0 & 0 & 0 & 0 & 0 & 0 & 0 & 0 & 0 & 0 & I & I & 0 & 0 & $\odot$ & $\odot$ & 0 & I & 0 & 0 & 0 & 0 & 0 & 0 & 0 & 0 & 0 & 0 & 0 & 0 & 3 \\
\hline C241 & Ampulla of Yater & 0 & 0 & 0 & 0 & 0 & 0 & 0 & 0 & 0 & 0 & 0 & 0 & 0 & 0 & 0 & 0 & 0 & 0 & $\odot$ & $\odot$ & $\odot$ & $\odot$ & $\odot$ & $\odot$ & $\odot$ & 0 & 0 & 0 & 0 & l & l \\
\hline C250 & Head of pancreas & 0 & 0 & 0 & 0 & l & 0 & 0 & $\mathbf{I}$ & 0 & 0 & 0 & $\odot$ & 0 & 0 & 0 & I & 0 & 0 & 0 & 0 & l & 0 & 0 & 0 & 0 & 0 & I & 0 & 0 & l & 6 \\
\hline CJOO & Nas: & 0 & 0 & 0 & 0 & 0 & 0 & 0 & 1 & 4 & 0 & 0 & 0 & 0 & 0 & 2 & 0 & 0 & 0 & 0 & 0 & 0 & 0 & 0 & l & 0 & 0 & 0 & 0 & 0 & 0 & 8 \\
\hline C310 & Max & 0 & 0 & 0 & 0 & 0 & 0 & l & 0 & 2 & 0 & $0 \quad$ & 0 & 1 & 0 & 3 & 0 & 1 & 0 & 0 & 0 & 0 & 0 & 0 & 0 & 0 & 0 & 0 & 0 & 1 & 0 & 9 \\
\hline C340 & nd lung & 0 & 0 & 0 & 0 & 0 & 0 & 0 & 0 & 0 & 0 & 20 & 0 & 0 & 0 & $\odot$ & $\odot$ & 2 & 1 & 0 & 0 & I & 0 & 4 & l & 0 & 0 & 2 & 0 & 2 & 3 & 18 \\
\hline C398 & $\begin{array}{l}\text { Overlapp less of } \\
\text { respir syst }\end{array}$ & & 0 & 0 & 0 & 0 & 0 & 0 & 0 & 0 & 0 & $0 \quad$ & 0 & 0 & 0 & 0 & & $\odot$ & $\odot$ & 0 & 0 & 0 & 0 & 0 & 0 & 0 & 0 & 0 & 0 & 0 & 0 & 2 \\
\hline C402 & L. bones of low.limb & 0 & l & & 0 & 0 & 0 & 0 & 0 & l & l & 20 & 0 & 0 & 0 & 0 & 1 & 0 & 0 & 0 & 0 & 0 & 0 & 0 & 0 & 0 & 0 & 0 & 1 & 0 & 0 & 8 \\
\hline C4I0 & $\begin{array}{l}\text { Bone.joint. and art. } \\
\text { cartilage of oau site }\end{array}$ & 0 & 0 & & 0 & 0 & 0 & 0 & 0 & 0 & 0 & 22 & 2 & 0 & 0 & 0 & 0 & 1 & 0 & 0 & 0 & l & 0 & 0 & 0 & I & 0 & 0 & 0 & l & 0 & 9 \\
\hline C421 & Bone m(IC & 8 & 5 & 3 & 0 & 0 & 0 & 0 & 0 & l & 0 & 0 & 0 & 0 & 0 & I & 0 & 0 & 0 & l & 0 & 0 & 0 & 0 & 0 & I & 0 & 0 & 0 & 1 & 0 & 21 \\
\hline C424 & $\begin{array}{l}\text { Hematopoietic } \\
\text { system.NOS }\end{array}$ & 0 & 0 & 0 & 0 & 0 & 0 & 0 & 0 & 0 & 0 & 0 & 0 & 0 & 0 & 0 & 0 & 0 & 0 & 0 & 0 & 0 & 0 & 0 & 0 & 0 & 0 & 0 & 0 & 0 & 0 & 0 \\
\hline C440-449 & Skin & 3 & 0 & I & l & 0 & 0 & 8 & 8 & 18 & 6 & 12 & 3 & & & 3 & 4 & 2 & 0 & 1 & I & 0 & 0 & 3 & I & 0 & 0 & 0 & 0 & 0 & 0 & 81 \\
\hline C480-482 & $\begin{array}{l}\text { Retroperitoneum and } \\
\text { pentoneum }\end{array}$ & 0 & 0 & 0 & 0 & 0 & 0 & 0 & 0 & 0 & 0 & 0 & 0 & & & 0 & 0 & & 0 & 0 & 0 & 0 & 0 & I & 0 & I & & I & 0 & l & 1 & 9 \\
\hline C490-499 & $\begin{array}{r}\text { Connective.SubcuLan } \\
\text { and othersofttisues }\end{array}$ & 0 & 0 & 0 & 0 & 0 & 0 & & & 2 & $\odot$ & 2 & $\odot$ & $\odot$ & $\odot$ & $\odot$ & & 3 & 0 & 0 & 0 & 0 & & $\odot$ & 0 & 0 & 0 & 0 & & & 0 & 15 \\
\hline C500-509 & Breast & 0 & 0 & 1 & 0 & 3 & 0 & & l & 11 & 5 & $34 \epsilon$ & 6 & 0 & 0 & 1 & l & & 0 & 3 & 2 & 8 & 13 & 11 & 2 & I & 0 & 3 & 4 & 8 & 3 & 125 \\
\hline C510-51 9 & Vulva & $\odot$ & $\odot$ & $\odot$ & $\odot$ & $\odot$ & I & 2 & $\odot$ & $\odot$ & 1 & $\odot$ & $\odot$ & I & 0 & I & 1 & 2 & 0 & 1 & l & 0 & 0 & 0 & 0 & 0 & 0 & 0 & 0 & 0 & 0 & $\mathrm{JI}$ \\
\hline C539 & Vagina & $\odot$ & $\odot$ & 0 & 0 & 0 & 0 & 2 & & 0 & 3 & $0 \quad$ & 0 & l & 0 & 0 & 0 & 0 & 0 & 0 & 0 & l & 0 & 0 & 0 & 0 & 0 & 0 & 0 & 0 & 0 & 8 \\
\hline C539 & Cervi & 2 & 4 & 1 & 1 & 4 & $\odot$ & ID & & & & W & 42 & 28 & 27 & 53 & 22 & 20 & 5 & 4 & 0 & 6 & 2 & 3 & 0 & 0 & 2 & 2 & I & 2 & 0 & 414 \\
\hline C541-549 & Cofl $>$ US uteri & 0 & $\odot$ & 0 & 0 & 0 & 0 & 0 & 0 & 4 & 2 & 0 & 1 & 0 & 1 & 1 & 2 & 0 & 0 & 1 & 0 & 0 & 0 & 1 & 0 & 0 & 0 & 0 & 0 & 0 & 0 & 13 \\
\hline C559 & Uterus & 0 & 0 & 0 & 0 & 0 & 0 & 1 & 0 & & 0 & 0 & 0 & 0 & 0 & 0 & 0 & l & 0 & 0 & 0 & 0 & 0 & 0 & 0 & 0 & 1 & 0 & 0 & 0 & 0 & 4 \\
\hline C569 & Ovary & 0 & 2 & 0 & 1 & 1 & 0 & 2 & 4 & 5 & 6 & 62 & 2 & 5 & $\odot$ & 5 & 2 & 3 & 2 & 1 & $\odot$ & $\odot$ & $\odot$ & 1 & $\odot$ & 0 & 1 & 1 & 0 & l & 0 & 51 \\
\hline C589 & Placenta & 0 & 0 & 1 & 1 & 1 & 0 & 1 & 2 & 0 & 6 & 93 & 3 & 0 & 0 & 0 & 0 & 0 & 0 & 0 & 0 & 0 & 0 & 0 & 0 & 0 & 1 & 0 & 1 & 0 & 0 & 26 \\
\hline C609 & Penis.NOS & 0 & 0 & $\odot$ & $\odot$ & 0 & 0 & 0 & & & $\odot$ & $1 \quad($ & 0 & 0 & 0 & 2 & 0 & 0 & 0 & 0 & 0 & 0 & 3 & 2 & 0 & 0 & 0 & 0 & 0 & 1 & 0 & 12 \\
\hline C619 & Prostate gland & 0 & 0 & 0 & 0 & 0 & 0 & I & 2 & & 0 & 2 & 4 & 0 & 0 & 0 & 0 & 0 & 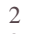 & 0 & 0 & 0 & 0 & 0 & 0 & 0 & 0 & 5 & 0 & 6 & 4 & 29 \\
\hline C629 & Descended testis & I & 0 & 0 & 0 & 0 & 0 & 0 & 0 & & 2 & 0 & 0 & l & 0 & 1 & 0 & 0 & 0 & 0 & 0 & 1 & 1 & 2 & 0 & $\odot$ & $\odot$ & $\odot$ & $\odot$ & 4 & $\odot$ & 14 \\
\hline C649 & Kidney & I & 0 & 0 & 0 & 0 & 0 & 6 & 0 & 0 & 0 & 0 & I & 1 & 1 & 1 & 0 & 3 & 0 & 0 & 0 & 0 & 1 & & 0 & 2 & 0 & 0 & 0 & 2 & 3 & 23 \\
\hline C679 & Bladd r & 0 & 0 & & 0 & 0 & 1 & & 1 & & 4 & 7 & 5 & $\odot$ & 2 & 2 & & 1 & I & $\rho$ & $\odot$ & 3 & $\odot$ & 2 & 1 & 0 & 0 & 0 & I & & I & 39 \\
\hline C690-699 & Eye & & 0 & & 1 & 1 & 0 & 11 & & 2 & 3 & 3 & 1 & 9 & 3 & 1 & 2 & 0 & 0 & 2 & 1 & 1 & 0 & 0 & 0 & 3 & 0 & 1 & 0 & 1 & 0 & 50 \\
\hline C700 & Meninges & $\odot$ & $\odot$ & $\odot$ & $\odot$ & $\odot$ & $\odot$ & $\odot$ & $\odot$ & & $\odot$ & 1 & 1 & 0 & 0 & 0 & 0 & 0 & 0 & 0 & 0 & 0 & 0 & 0 & 0 & 0 & 0 & 0 & 0 & 0 & 0 & 3 \\
\hline C710-719 & Brain & $\odot$ & $\odot$ & $\odot$ & $\odot$ & $\odot$ & $\odot$ & & $\odot$ & 3 & 2 & 5 & I & 0 & 0 & 0 & l & 0 & 1 & 0 & 0 & 0 & 0 & 0 & 0 & 0 & 0 & 0 & 1 & 0 & 0 & 15 \\
\hline C720.729 & $\begin{array}{l}\text { Spinal cord. cran.n. } \\
\text { and oth parts of CNS }\end{array}$ & 0 & & 0 & 0 & 0 & 0 & 0 & 0 & 0 & & I & 0 & 0 & 0 & 0 & 0 & 0 & 0 & 0 & 0 & 0 & 0 & 0 & 0 & 0 & 0 & 0 & 0 & 0 & 0 & 3 \\
\hline C7W & Thyroid gland & 0 & 0 & 0 & 0 & 0 & 0 & 3 & I & 6 & 5 & 12 & 4 & I & 1 & 2 & 0 & & 0 & 0 & 2 & 3 & I & 6 & 3 & & $\odot$ & 2 & $\odot$ & & 0 & 55 \\
\hline C750-759 & $\begin{array}{l}\text { Others endocrine gl } \\
\text { and rel structures }\end{array}$ & 0 & $\odot$ & $\odot$ & $\odot$ & $\odot$ & $\odot$ & I & $\odot$ & $\odot$ & $\odot$ & 2 & 1 & $\odot$ & $\odot$ & $\odot$ & $\odot$ & & 0 & 0 & 0 & 0 & 0 & 0 & 0 & & 0 & $\mathrm{u}$ & 0 & & 0 & 7 \\
\hline C760-768 & $\begin{array}{l}\text { Others and ill defined } \\
\text { sites }\end{array}$ & $\odot$ & ( ) & () & () & $\odot$ & $\odot$ & 2 & & $\odot$ & $\odot$ & $\odot$ & $\odot$ & & 0 & 0 & 0 & 0 & 0 & & 0 & 2 & 2 & 0 & & 2 & & $\odot$ & $\odot$ & $\odot$ & ( ) & 13 \\
\hline C770-779 & Lvmph nodes & 0 & ll & 0 & 0 & 0 & 0 & I & 0 & 2 & 0 & & 0 & 0 & & & & 3 & 0 & 2 & 2 & 9 & 0 & 3 & 0 & 2 & () & & 1 & 0 & 0 & 32 \\
\hline & All silts & 18 & 14 & 12 & & 13 & 2 & 87 & 71 & 145 & $\pi 31$ & 1724 & 96 & 514 & 41 & 5 & & 121 & 182 & & 185 & 555 & 559 & 972 & 27 & 16 & $\pi$ & 28 & & 42 & & 1484 \\
\hline & Pcrcenuige & 1.2 & & & & & & 16 & 5.2 & 9.81 & & U3. & .314. & & .86 & .11 & & & & & 1.2 & 5.7 & & 6.5 & t.81 & 1.1 & & & & & & 1500 \\
\hline
\end{tabular}

S1.0 - in situ. SL I = localized. SL : ! - direct •tension. St. $3=$ regionol lymph nodes involvement, St. 4 = distant metastases

l=illiteraLc. A=Able to read and write. E=Elementary. JH=Junior High School, SH=Senior High School, Ac= Academy/Universily

Cases with unknown education level (159) as well as cases wllh unknown chnical extent of disease (501) were excluded 
Table ix. Numbers of histologically confirmed new cases in ten most frequent cancers by histologic type

\begin{tabular}{|c|c|c|c|c|}
\hline ICD-0 & Site & Morphology & No & $\%$ \\
\hline \multirow[t]{5}{*}{ C 539} & \multirow{5}{*}{$\begin{array}{l}\text { Cervix } \\
(n=482)\end{array}$} & Carcinoma, Nos• & 19 & 3.9 \\
\hline & & Squamous cell carcinoma, keratinizing & 291 & 60.4 \\
\hline & & Adenocarcinoma & 84 & 17.4 \\
\hline & & Squamous cell carcinoma, non keratinizing & 68 & 14.1 \\
\hline & & Others & 20 & 4.1 \\
\hline \multirow[t]{6}{*}{ C $110-119$} & \multirow{6}{*}{$\begin{array}{l}\text { Nasopharynx } \\
(n=I 95)\end{array}$} & Undifferentiated carcinoma & 154 & 79 \\
\hline & & Carcinoma, NOS & 21 & 10.8 \\
\hline & & Lymphoma malignant & 3 & 1.5 \\
\hline & & Squamous cell carcinoma, keratinizing & 2 & $\mathbf{I}$ \\
\hline & & Squamous cell carcinoma, non keratinizing & 2 & 1 \\
\hline & & Others & 13 & 6.7 \\
\hline \multirow[t]{11}{*}{ C 500-509 } & \multirow{11}{*}{$\begin{array}{l}\text { Breast } \\
(\mathrm{n}=172)\end{array}$} & Non Invasive Intraductal carcinoma & 6 & 3.5 \\
\hline & & Invasive Invasive ductal carcinoma & 100 & 58.1 \\
\hline & & Invasive lobular carcinoma & 10 & 5.8 \\
\hline & & Squamous cell carcinoma & 2 & 1.2 \\
\hline & & Mucinous carcinoma & 1 & 0.6 \\
\hline & & Papillary carcinoma & 1 & 0.6 \\
\hline & & Adenoid cystic carcinoma & $\mathbf{I}$ & 0.6 \\
\hline & & Carcinoma, NOS & 35 & 20.3 \\
\hline & & Paget's disease of the nipple & 3 & 4.2 \\
\hline & & Cystosarcoma phylloides & 3 & 4.2 \\
\hline & & Others & 10 & 5.8 \\
\hline \multirow[t]{14}{*}{ C 421} & \multirow{14}{*}{$\begin{array}{l}\text { Bone marrow } \\
(\mathrm{n}=171)\end{array}$} & Acute lymphoblastic leukemia & 86 & 50.3 \\
\hline & & Acute myeloid leukemia & 16 & 9.4 \\
\hline & & Acute monocytic leukemia & 13 & 7.6 \\
\hline & & Acute leukemia, NOS & 7 & 4 \\
\hline & & Acute myelomonocytic leukemia & 6 & 3.5 \\
\hline & & Acute promyelocytic leukemia & 2 & 1.2 \\
\hline & & Acute prolymphocytic leukemia & 1 & 0.6 \\
\hline & & Chronic myeloid leukemia & 22 & 12.9 \\
\hline & & Chronic lymphocytic leukemia & $\mathbf{I}$ & 0.6 \\
\hline & & Chronic myelomonocytic leukemia & 1 & 0.6 \\
\hline & & Leukemia, NOS & 【 & 0.6 \\
\hline & & Multiple myeloma & 6 & 3.5 \\
\hline & & Polycythemia vera & 6 & 3.5 \\
\hline & & Others & 3 & 1.8 \\
\hline \multirow[t]{8}{*}{ C $180-209$} & \multirow{8}{*}{$\begin{array}{l}\text { Colorectal } \\
(n=l 15)\end{array}$} & Adenocarcinoma & 78 & 68.4 \\
\hline & & Mucinous adenocarcinoma & 10 & 8.8 \\
\hline & & Follicular adenocarcinoma & 8 & 7 \\
\hline & & Carcinoma, NOS & 2 & 1.7 \\
\hline & & Signet ring cell carcinoma & 5 & 4.4 \\
\hline & & Malignant carcinoid & 1 & 0.9 \\
\hline & & Adenosquamous carcinoma & 1 & 0.9 \\
\hline & & Others & 9 & 8 \\
\hline
\end{tabular}




\begin{tabular}{|c|c|c|c|c|}
\hline \multirow[t]{4}{*}{ C 778-779 } & \multirow{4}{*}{$\begin{array}{l}\text { Lymph nodes } \\
(n=108)\end{array}$} & Non Hodgkin's lymphoma & 95 & 86.4 \\
\hline & & Hodgkin's disease & 5 & 4.5 \\
\hline & & Burkitt's lymphoma & 4 & 3.6 \\
\hline & & Others & 4 & 4 \\
\hline \multirow[t]{6}{*}{ C $440-449$} & \multirow{6}{*}{$\begin{array}{l}\text { Skin } \\
(n=102)\end{array}$} & Basal cell carcinoma & 51 & 50 \\
\hline & & Squamous cell carcinoma & 29 & 28.4 \\
\hline & & Malignant melanoma & 8 & 7.8 \\
\hline & & Sebaceous adenocarcinoma & 3 & 2.9 \\
\hline & & Dermatofibrosarcoma & 2 & 2 \\
\hline & & Others & 9 & 8.8 \\
\hline \multirow[t]{4}{*}{ C 739} & \multirow{4}{*}{$\begin{array}{l}\text { Thyroid } \\
(n=77)\end{array}$} & Papillary carcinoma & 49 & 63.6 \\
\hline & & Follicular carcinoma & 12 & 15.6 \\
\hline & & Carcinoma anaplastic, NOS & 9 & 11.7 \\
\hline & & Others & 7 & 9.1 \\
\hline \multirow[t]{9}{*}{ C 690-699 } & \multirow{9}{*}{$\begin{array}{l}\text { Eye } \\
(n=62)\end{array}$} & Squamous cell carcinoma & 16 & 25.8 \\
\hline & & Retinoblastoma & 13 & 21 \\
\hline & & Embryonal rhabdomyosarcoma & 8 & 12.9 \\
\hline & & Adenocarcinoma & 5 & 8.1 \\
\hline & & Basal cell carcinoma & 4 & 6.5 \\
\hline & & Malignant melanoma & 3 & 4.8 \\
\hline & & Neuroblastoma & 2 & 3.2 \\
\hline & & Transitional cell carcinoma & 2 & 3.2 \\
\hline & & Others & 9 & 14.5 \\
\hline \multirow[t]{9}{*}{ C 569} & \multirow{9}{*}{$\begin{array}{l}\text { Ovary } \\
(n=60)\end{array}$} & Adenocarcinoma NOS & 21 & 35.6 \\
\hline & & Papillary cystadenocarcinoma & 11 & 18.6 \\
\hline & & Mucinous cystadenocarcinoma & 5 & 8.5 \\
\hline & & Dysgerminoma & 4 & 6.8 \\
\hline & & Endometrioid carcinoma & 3 & 5.1 \\
\hline & & Serous cystadenocarcinoma & 2 & 3.4 \\
\hline & & Granulosa cell tumor & 1 & 1.7 \\
\hline & & Clear cell adenocarcinoma & 1 & 1.7 \\
\hline & & Others & 7 & 11.7 \\
\hline
\end{tabular}

NOS $=$ Not Otherwise Specified 